\title{
CERCETĂRI ARHEOLOGICE PREVENTIVE ÎN JUDEȚUL GIURGIU
}

\author{
CĂTĂLIN BEM, ADRIAN VLADU \\ ADRIAN BĂLĂȘESCU, VALENTIN RADU
}

\section{REZUMAT:}

Lucrările de implementare a proiectului BRUA au impus și realizarea evaluării arheologice a traseului magistralei pentru gaze naturale și, apoi, implicit, în funcție de situații, a cercetărilor arheologice preventive. În cele ce urmează, ne vom opri asupra unor rezultate punctuale din zona de traseu BRUA din centrul județului Giurgiu Mirău (com. Stoenești). Stratigrafia sitului este predominant naturală. Toate intervențiile stratigrafice (un foarte probabil sondaj de diagnostic - $\mathrm{Cx} 2$, două gropi medievale $-\mathrm{Cx} 1$ și $\mathrm{Cx} 3$, precum și o serie de stâlpi de lemn pe care îi atribuim unor împrejmuiri din anii 70-80 ai sec. al XX-lea) afectează un nivel de sol antic și sunt, stratigrafic, acoperite de nivelul celui actual, arat. Ceramica și resturile arheozoologice sunt singurele materiale descoperite şi recuperate. Provin exclusiv din cuprinsul celor două complexe medievale. Chiar dacă inventarul Cx3 este mai slab cantitativ, caracteristicile ambelor categorii sunt unitare, dovedind atât o contemporaneitate, cât și manifestări și comportamente identice.

În cadrul ansamblului ceramic al $\mathrm{Cx} 1$ au fost identificate și definite cinci categorii de pastă; materialul este parțial întregibil. Materialul ceramic descoperit în Cx3 este foarte fragmentar și în totalitate neîntregibil. Au fost identificate numai două categorii principale de pastă ( $\mathrm{P} 1$ și $\mathrm{P} 2$, prezente și în cadrul ceramicii provenite din $\mathrm{Cx} 1)$, cu variante nesemnificative. Datăm cele două complexe undeva în sec. al XVI-lea. Datarea materialului ceramic concordă cu prima atestare documentară a Mirăului. Chiar dacă cele două gropi au fost săpate pentru utilizarea sedimentelor - ea însăși o activitate nefirească, extragerea lutului fiind mai facilă din marginea terasei -, ele au fost folosite ulterior pentru redepozitare de deșeuri (?), inclusiv de resturi a numeroase focuri domestice.

În cadrul economiei animaliere de la Mirău se creșteau o serie de animale domestice, printre acestea bovinele sunt predominate, ele fiind urmate de către ovicaprine și porcine care își dispută locul doi. Bovinele erau exploatate de o manieră mixtă (carne și lapte), dar nu trebuie omisă nici contribuția acestora la tracțiune (ca forță de muncă), în timp ce ovicaprinele erau crescute pentru produsele lor secundare (lapte și lână). Remarcăm consumul alimentar al calului (hipofagia) care probabil era ocazional. Acest fenomen este întâlnit de o manieră izolată în evul mediu românesc în ciuda interdicțiilor religioase. În cazul de faţă, ne putem gândi fie la un moment de criză alimentară, fie la valorificarea în alimentație a animalelor bătrâne/accidentate. Rezultatele acestui studiu includ utilizarea în alimentație și a peștilor (știuca, plătica, crapul, șalăul și somnul) și a păsărilor domestice (găina și gâsca).

O serie de fragmente ceramice, ținând cont de caracteristicile fabric-ului, sunt preistorice - cel mai probabil, gumelnițene. Firește, sunt elemente intruzive în complexul respectiv.

Informațiile de natură stratigrafică sunt pe deplin completate de cele arheozoologice. Lăsând deoparte rațiunile pentru care au fost săpate cele două gropi - estimăm că momentul principal de umplere antropică, plasat cronologic la scurt timp după excavare, s-a petrecut în sezonul cald, pentru ca, momentul principal de umplere naturală să aparțină sezonului rece. Revenirea antropică sesizată în cazul Cx1 se va fi petrecut la sfârșitul acestui sezon rece sau la debutul sezonului cald următor, dar nu are absolut niciuna din caracteristicile anterioare.

Din păcate, cunoaștem foarte puțin despre locuirile rurale medievale din Țara Românească, cu elemente decelate pentru a putea fi comparate.

\section{Abstract: Preventive archaeological survey in Giurgiu County.}

The implementation works for the BRUA project imposed the making of an archaeological evaluation for the route taken by the natural gas line and, implicitly, depending on the situations, of archaeological rescue excavations. In the following, we will focus on specific results from the BRUA route area in the center of Giurgiu country - Mirău (Stoenești commune). The stratigraphy of the site is predominantly natural. All stratigraphic interventions (a very probable diagnostic survey $-\mathrm{Cx} 2$, two medieval pits $-\mathrm{Cx} 1$ and $\mathrm{Cx} 3$, also a series of wooden poles that we atribute to some fencing works made during the 70's and 80's of the twentieth century) affect a level of ancient soil and are, stratigraphicaly, covered by the level of the current one, ploughed. The pottery and archaeozoological remains are the only materials discovered and recovered. Even if the inventory of $\mathrm{Cx} 3$ is weaker from a quantitative point of 
view, the characteristics of both categories are unitary, proving both contemporaneity and identical manifestations and behaviors.

Within the ceramic assembly $\mathrm{Cx} 1$ five categories of paste have been identified and defined; the material is partially completable. The pottery fragments discovered in $\mathrm{Cx} 3$ is very fragmentary and totally uncompletable. Just two main paste categories have been identified ( $\mathrm{P} 1$ and $\mathrm{P} 2$, present also among the pottery from $\mathrm{Cx} 1$ ), with insignificant variations. We date the two contexts somewhere in the sixteenth century. The dating of the pottery is in accrod with the first documentary mention of Mirău. Even if the two pits have been dug for using the sediments - itself being an unatural activity due to the fact that clay extraction can be more easily made from the edge of the terrace -, they were later used for redepositing waste (?), including the remains of numerous domestic fires...

Within the animal economy from Mirău a series of domestic animals were bred, among these bovines are predominant, being followed in second place by ovicaprines and swines. Bovines were exploited in a mixed manner (meat and dairy), but their contribution as draft animals must not be omitted, while ovicaprines were bred for their secondary produce (dairy and wool). We notice that the use of the horse as a food source (hypophagy) was probably occasional. This phenomenon is encountered in an isolated manner in the Romanian Middle Ages in spite of religious prohibitions. In this case, we can either think about a time of food crisis or about the recovery in food of old/ injured animals. The results of this study include the use of fish (pike, bream, carp, perch and catfish) and domestic birds (chicken and goose) as a food source.

A series of pottery fragments, taking into consideration the characteristics of their fabric, are prehistoric - most probably belonging to the Gumelnița culture. Of course, these are intrusive elements in that certain context.

Informations of a stratigraphic nature are fully completed by the archaeozoological ones. Leaving aside the motivation for which the two pits were dug - we estimate that the main moment of anthropic filling, chronologically placed in short time after the excavation, happened during the warm season, in order that the main moment of natural filling to happen during the cold season. The anthropic return noticed in the case of $\mathrm{Cx} 1$ had happened at the end of this cold season or at the begining of the following warm season, but has absolutely none of the previous characteristics.

Sadly, we know very little about the rural medieval habitation in Wallachia, with discerned for comparison...

CUVINTE CHEIE: cercetare arheologică preventivă, Gumelniţa, perioadă medievală, ceramică, arheozoologie

KEYWORDS: preventive archaeological survey, Gumelnița culture, Middle Ages, pottery, zooarchaeology¹.

Lucrările de implementare a proiectului BRUA au impus și realizarea evaluării arheologice a traseului magistralei pentru gaze naturale și, apoi, implicit, în funcție de situații, a cercetărilor arheologice preventive. În cele ce urmează, ne vom opri asupra unor rezultate punctuale din zona de traseu BRUA din centrul județului Giurgiu (Fig. 1).

Unul dintre siturile ${ }^{2}$ arheologice în discuție este situat la aproximativ $150 \mathrm{~m}$ nord - nord-est de ieșirea din satul Mirău, spre Tangâru (sat înglobat în actualul Stoenești), în zona unor foste grajduri demolate în anii ' 80 ai secolului trecut (Fig. 2-3), la 500 m vest - sud-vest de cimitirul fostului sat Tangâru. Pentru că la suprafața solului nu au fost descoperite materiale arheologice, pe toate hărțile sau fotografiile aeriene verticale sau oblice situl este marcat exclusiv prin secțiunea cercetată de către colectivul nostru³.

Stațiunea este amplasată pe terasa (săpată) dreapta a Câlniștei, la aproximativ $900 \mathrm{~m}$ sud de actualul curs al pârâului, la cca 450 est de zona de debușare în luncă a Văii Râcu. Diferența relativă de nivel este de cel puțin $30 \mathrm{~m}$ (Fig. 2). Erodarea terasei Câlniștei de către pârâu, dar și de către Valea Râcu - a creat impresia unui golf larg (Fig. 2; Fig. 5), aproximativ în centrul segmentului său estic fiind situat situl.

\footnotetext{
Translated by Eduard Ghinea.

2 Situl arheologic S1 - sat Mirău a fost identificat și delimitat în conformitate cu rezultatele consemnate în Raportul de diagnostic arheologic intruziv „,Conductă de transport gaze naturale zona Țărmul Mării Negre - Podișor: situl arheologic Clejani - „La carieră” (cod RAN: 101993.01, cod LMI: GR-I-s-B-14770), situl arheologic așezarea de la Prundu - „Lacul Greaca" (cod RAN:104699.04, cod LMI:GR-I-S-B-14821), situl arheologic S1, situl arheologic S2, situl arheologic S3, situl arheologic S4, situl arheologic S5, situl arheologic S6, situl arheologic S7 - jud. Giurgiu”.

3 La cercetările de teren, având ca instituție organizatoare Muzeul Județean ”Teohari Antonescu” Giurgiu, au participat și colegii Iulia Răbîncă, Adrian Gligor și Cătălin Borangic.
} 
Parte integrantă a Câmpiei Burnasului (element component al Câmpiei Române), terasa ${ }^{4}$ pe care s-a dezvoltat stațiunea de la Mirău este dominată de prezența majoritară a depozitelor lœssoide din Pleistocenul mediu și superior, deluvial-proluviale, care acoperă o serie de depuneri de pietrișuri și nisipuri din Pleistocenul inferior, aflate în zona sitului la zi (de o parte și de alta a Văii Râcu). Firește, zona de luncă a Câlniștei, din imediata apropiere nordică, este marcată de argile și nisipuri/pietrișuri din Holocenul superior, dar și de depozite lœssoide aparținând Holocenului inferior (Fig. 4).

Pentru satul Mirău nu este reținut niciun sit arheologic în Repertoriul Arheologic Național și, implicit, nici în Lista Monumentelor Istorice.

Pentru a încerca integrarea descoperirilor noastre într-un ansamblu microzonal, am apelat la o serie de descoperiri arheologice edite, utilizând totodată informațiile oferite de raportul de diagnostic, precum şi la resurse cartografice.

Astfel, în cazul satului Stoenești, în ambele baze de date este menţionat cunoscutul ${ }^{5}$ tell Boian și Gumelniţa (adăpostind și locuiri din epoca bronzului şi Hallstatt) Măgura Tangâru (aflat față de situl cercetat preventiv de către colectivul nostru, în linie dreaptă, la cca 2,4 km nord-est) ${ }^{6}$.

Cele mai apropiate stațiuni arheologice față de cea de la Mirău - fără a insista -, sunt cele de la Schitu (începând de pe versantul vestic al amintitului golf format în zona debușeului Văii Râcu în lunca pârâului Câlniștea) și cele de la Bila (pe terasa stânga a Câlniștei, vis-à-vis de zona noastră de interes, ambele în com. Schitu, jud. Giurgiu). Siturile se află la distanțe cuprinse aproximativ între 2 și $2,5 \mathrm{~km}$ în linie dreaptă faţă de cel de la Mirău.

Reținem în acest context polul Boian-Gumenița de pe Măgura Tangâru și două, foarte probabil, locuiri temporare/ sezoniere Boian, dar și locuiri din epoca Bronzului (Glina - trei, Tei - trei), Hallstatt (Basarabi - una), din secolele III-II a. Chr. (trei), secolul al IV-lea p. Chr. (cinci) și secolele VIII-IX (Dridu - două) ${ }^{7}$. Ne-am fi așteptat ca cel puțin una dintre aceste perioade crono-culturale să fie bine reprezentată și în situl de la Mirău.

Cercetarea preventivă a sitului s-a realizat printr-o unică secțiune magistrală, având o suprafață totală de 156x2,2 m². Stratigrafia este predominant naturală și este unitară pe întreaga secțiune magistrală (Fig. 10-11). Solul actual (1), un sediment siltic eterogen, necompact, brun mediu-cenușiu, arat, având o grosime de $25-35 \mathrm{~cm}$, s-a format în dauna unui sol antic (2) siltic, omogen, compact, brun închis-cenuşiu, fără constituenți antropici in situ (rarele fragmente subcentimetrice de materiale contemporane de construcție sunt intruzive), având o grosime care variază, în funcție de adâncimea arăturii, între 15 și $30 \mathrm{~cm}$. Mai cu seamă la baza solului actual și, rareori, la partea superioară a celui antic se concentrează o serie de materiale de construcție, fragmente ceramice, piese metalice, toate contemporane, provenind, fără îndoială, de la fostele grajduri din perioada comunistă, demolate în anii '80 ai secolului al XX-lea. Toate intervențiile stratigrafice (un foarte probabil sondaj de diagnostic - Cx2, două gropi medievale $-\mathrm{Cx} 1$ și Cx3, precum și o serie de stâlpi de lemn pe care îi atribuim unor împrejmuiri în legătură cu amintitele grajduri) afectează nivelul de sol antic și sunt, stratigrafic, acoperite de nivelul celui actual.

În sfârșit, un nivel natural (3), siltic-argilos, omogen, compact, galben-brun mediu, fără constituenți antropici, cu limită superioară netă, completează stratigrafia naturală a sitului de la Mirău.

Indicativele nivelurilor se regăsesc pe fotografii și în desene.

De câte ori va fi nevoie, vom puncta ceea ce am menționat şi cu alte prilejuri. Sintagma strat de cultură, cel mai adesea, nu reflectă o realitate nici măcar stratigrafică. Întotdeauna, un strat de cultură trebuie să aibă o matrice sedimentară de origine antropică. Unde ea nu există, nu există strat de cultură. Acumularea unor materiale arheologice - care marchează, firește, un orizont crono-cultural -, ele singure nu pot defini un strat de cultură, ci numai o prezență antropică în proximitatea suprafeței cercetate.

Firește, în cazul Mirăului, excepții privind identitățile stratigrafice se referă la prezența intervențiilor antropice de interes arheologic. Astfel, ambele complexe identificate şi cercetate sunt gropile medievale (Cx1 şi Cx3). Acestea perforează nivelul (2) și, firește, nivelul (3), umplutura fiind acoperită de nivelul (1). Fără îndoială, fundul gropilor este mult sub limita superioară a nivelului de loess al terasei (3). Diagrama stratigrafică generală a poziționării lor este redată mai jos.

\footnotetext{
4 Probabil, datorită scării mari a hărții geologice (http://www.geo-spatial.org/download/harta-geologica-a-romanieiscara-1-200-000) şi a unor erori inerente care însoțesc georefențierea, amplasamentul secțiunii noastre de cercetare pare a fi în luncă. Firește, nu aceasta este situația.

5 Berciu 1935; Berciu 1937; Berciu 1959a; Berciu 1959b; Berciu 1961; Bem et al. 2012.

6 Deși primele cercetări arheologice s-au realizat în perioada interbelică și multe rezultate au fost publicate, și de această dată RAN reține erori nejustificate. Apartenența la comuna Florești-Stoenești, amplasarea pe pârâul Sabar, dimensiunile neconforme cu realitatea sau fazele crono-culturale ale depunerilor antropice sunt printre cele mai evidente. În atari condiții, nu este exclus ca și codul RAN să fie fals, dacă atribuirea administrativă este greșită. Curios este și faptul că lista bibliografică include două titluri care ar fi trebuit să poziționeze corect descoperirile.

7 http://ran.cimec.ro/.
} 


\section{Cx1 (Fig. 11-15)}

Cel mai probabil, a avut o formă ovală alungită (aproximativ cu diametrul mare perpendicular pe profilul magistral general estic al secțiunii noastre, pe direcția nord - nord-est - sus - sud-est), fiind secționată întrucâtva pe diametrul mic (Fig. 12/1), la nivelul de identificare având cca 1,6 m. Diametrul mare poate fi estimat la cel puțin $2,5 \mathrm{~m}$, la același nivel. Secțiunea are o formă generală tronconică, continuată cilindric spre gură (Fig. 12/2). Adâncimea maximă pe care am certificat-o este de $2,45 \mathrm{~m}$.

Săpată, probabil, pentru extragerea lutului (deși acțiunea era mai facilă din marginea terasei), are cel puțin două momente principale de umplere. Succesiunea stratigrafică, de sus în jos, este următoarea (indicativele se regăsesc pe desene și profile):

US11 - sediment siltic, eterogen, puțin compact, brun mediu, cu rari constituenți antropici, milimetrici (intruzivi) - corespunde unei umpleri naturale,

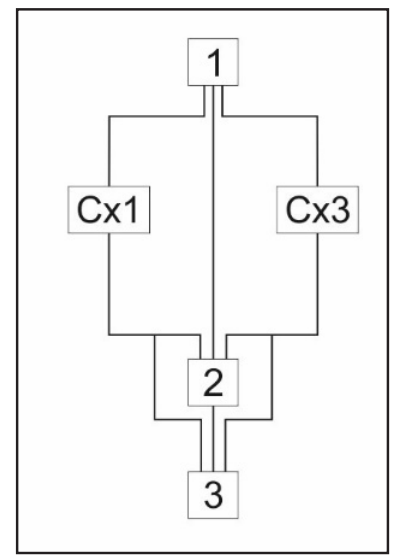

US12 - sediment argilos, omogen, compact, brun - galben închis cu nuanțe roșiatice, fără constituenți antropici corespunde unei degradări accentuate a pereților și sedimentelor exterioare (2), din cauze naturale,

US13, US15 - sedimente argiloase, omogene, compacte, brun mediu-cenușii, cu rari constituenți antropici corespund aceleiaşi degradări accentuate a pereților și a sedimentelor exterioare (2), din cauze naturale,

US14 - are aceleași caracteristici ca precedentele două, inclusiv din punct de vedere al interpretării, cu diferența că include fragmente de cărbune $(1-5 \mathrm{~cm})$,

US16 - sediment siltic, eterogen, compact, brun mediu-cenuşiu închis, cu numeroase concrețiuni carbonatice și rare fragmente ceramice și cărbune (1-2 cm) - corespunde unei acțiuni conştiente de umplere (Cx1 sup.), ultima cronologic, urmată la scurt timp de un aport important de apă care a antrenat sedimente exterioare, a omogenizat și a condus la formarea amintitelor concrețiuni,

US17 - sedimente siltice organizate lenticular, omogene, foarte compacte, brun închis-cenuşii, cu relativ numeroase fragmente subcentimetrice de cărbune - corespund cu foarte mare probabilitate unei faze de umplere naturală, cu antrenarea din exterior a cărbunelui (?),

US18, US21 - sedimente argiloase, omogene, foarte compacte, galben-brun mediu-cenușii, fără constituenți antropici - sunt consecința, fără îndoială, a prăbușirii de fragmente din pereții gropii,

US19 - sediment argilos, omogen, compact, brun închis-cenușiu, cu numeroși constituenți antropici (fragmente ceramice, resturi osoase - de mamifere, păsări, pești -, numeroase fragmente de cărbune) - corespunzând unei acțiuni de umplere conștientă,

US20 - sediment siltic, omogen, foarte compact, brun mediu-cenușiu-roșcat, cu numeroase fragmente subcentimetrice de cărbune, corespunzând unei posibile acțiuni de umplere conştientă,

US22, US24 - cenușă organizată lenticular, cu numeroși constituenți antropici, inclusiv milimetrici (fragmente ceramice, resturi osoase - de mamifere, păsări, pești -, cărbune, inclusiv de vegetație de baltă - trestie, papură) este puțin probabil să fie rezultatul unor focuri pe loc, în condițiile în care pereții gropii nu sunt deloc impresionați termic - sunt rezultatul unor redepozitări de material rezultat în urma unor focuri domestice,

US23 - lentilă de sediment siltic omogen, ars și, în consecință, foarte compact, brun deschis-gălbui - probabil, resturile unei vetre dezafectate (?), redepozitate,

US25 - sediment siltic, eterogen, compact, brun mediu-cenușiu închis, include concrețiuni carbonatice și numeroase fragmente de cărbune $(1-2 \mathrm{~cm})$ - corespunde debutului umplerii intenționate.

O simplă lectură a diagramei stratigrafice, mai jos prezentată, indică existența a patru momente de umplere. Cel dintâi (primul cronologic) se datorează unei acțiuni conștiente antropice de umplere - unitățile stratigrafice 25 , 24, 23, 22 și 19. Fractura reprezentată de US20 poate fi explicată prin remanierea locală a unei mici părți a sedimentului de la suprafața US19, pe panta proprie, umplând gravitațional diferența de nivel de deasupra US21.

Urmează un moment de umplere naturală - reprezentat de unităţile stratigrafice 21,18 și 17 - format mai cu seamă din fragmente de relativ mari dimensiuni desprinse din pereții gropii și marcând foarte probabil un abandon relativ al structurii de locuire - poate, timp de un sezon.

Revenirea antropică este marcată de o singură unitate stratigrafică, 16 (Cx1 sup), suficient de dezvoltată pentru a individualiza un moment de umplere.

În sfârșit, abandonul final - al structurii de locuire și al gropii în sine ca element cunoscut - este constituit stratigrafic de US11-US15, rezultate ale degradărilor de amploare ale pereților și sedimentelor imediat exterioare. Pe verticală ocupă mai bine de jumătate din întreaga acumulare. 
O diagramă stratigrafică a $\mathrm{Cx} 1$ cu evidențierea momentelor de umplere este redată mai jos.

Marea majoritate a materialului arheologic, unitar și fără diferențe (de aceea va fi și tratat ca un ansamblu), provine din US19, US22 și US24, mai mult de 95\% aparţinând primului moment de umplere.

$\mathrm{Au}$ fost prelevați, în plus, câte 30 de litri de sediment din unitățile stratigrafice 22 și 24, sitaţi la umed și, apoi, materialul rezultat triat.

\section{Cx3 (Fig. 11; Fig. 16-19)}

Cel mai probabil, a avut o formă cvasi-circulară în plan, la gură, la nivelul identificării (Fig. 16/1), şi mai ales o secțiune cilindrică (Fig. 16/2; Fig. 17). Diametrul maxim estimat se cifrează în jurul a 1,60 m iar adâncimea maximă este de cca 1,70 m. Se poate observă că raportul dintre diametrul maxim și adâncime, în cazul ambelor gropi, este de aproximativ 1.

O diagramă stratigrafică a Cx3 cu evidențierea momentelor de umplere este redată mai jos.

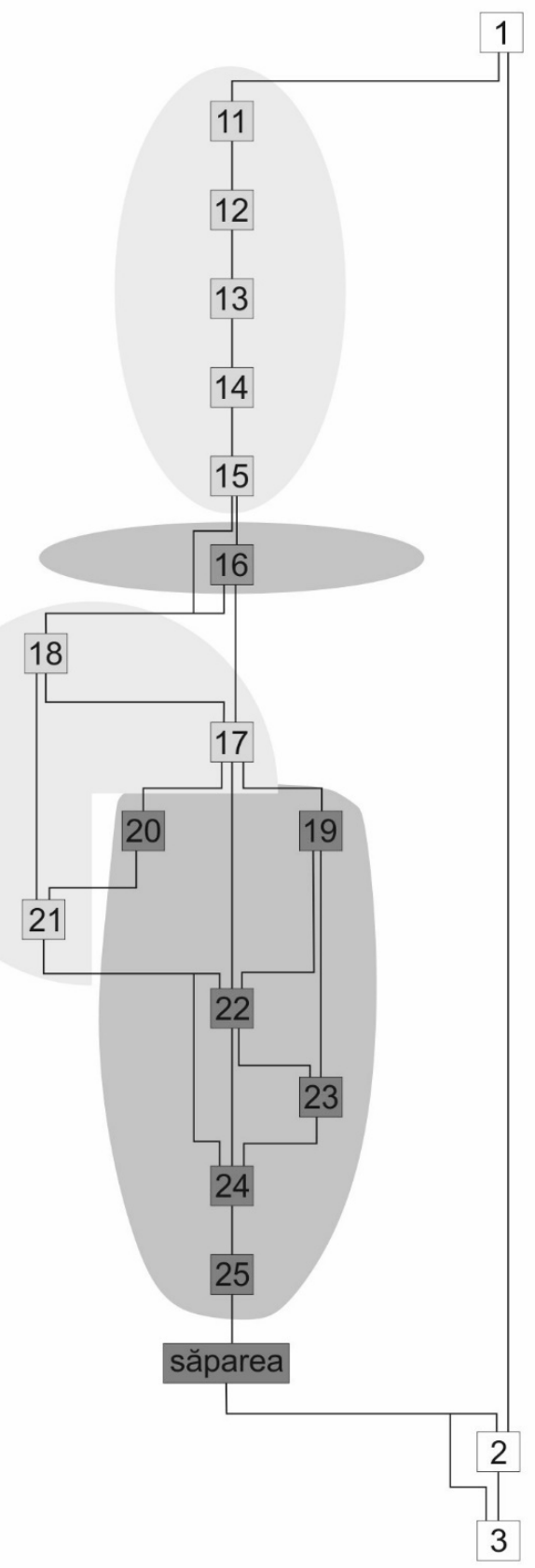

CX1

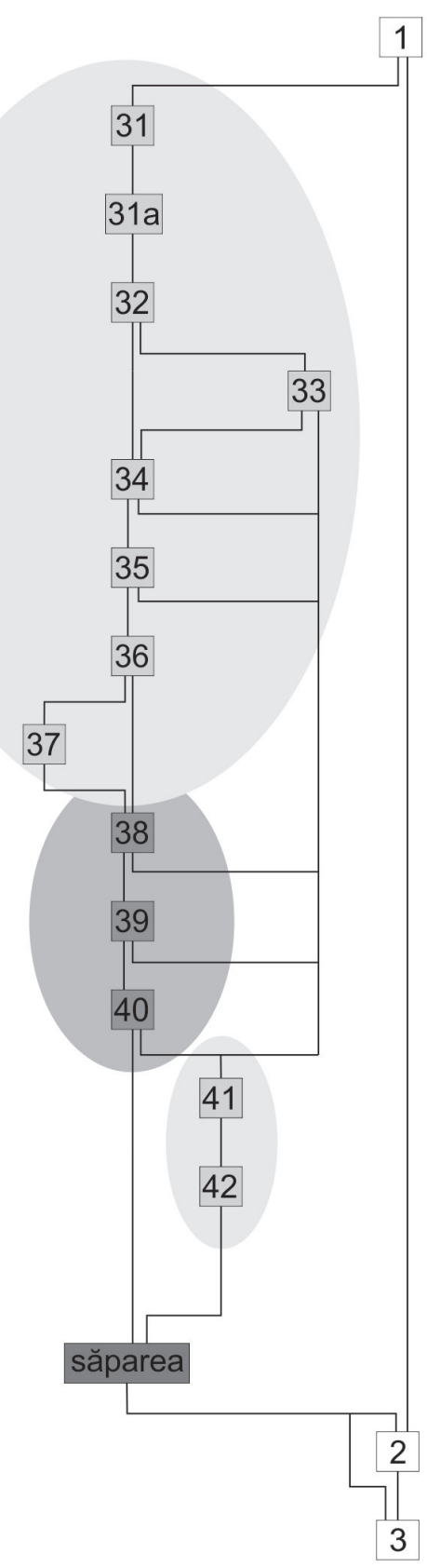

CX3 
Ca şi Cx1, groapa în cauză a fost săpată, probabil, pentru extragerea lutului.

Succesiunea stratigrafică, de sus în jos este următoarea (indicativele se regăsesc pe desene și profile):

US31 - cvasi-identică cu US11,

US31a - cvasi-identică cu US12,

US32 - cvasi-identică cu US13,

US33, US34, US35, US36, US41, US42 - sedimente argiloase, omogene, compacte, brun mediu-cenușiu-gălbui, cu extrem de rari constituenți antropici (?) (exclusiv fragmente milimetrice de cărbune - numai US33 și US41) corespunde unei degradări accentuate a pereților, din cauze naturale,

US37 - sediment argilos, omogen, compact, brun deschis-gălbui, fără constituenți antropici - corespunde aceleiași degradări accentuate a pereților, din cauze naturale,

US38 - cvasi-identică cu US22 și US24 - așadar rezultat al unei acțiuni de umplere conștientă,

US39 - sediment siltic, omogen, compact, brun mediu-cenușiu deschis; rari constituenți antropici, numeroși oxizi de fier, posibil rezultat al unei acțiuni de umplere conștientă,

US40 - sediment siltic, omogen, compact, organic, cu numeroase fragmente de cărbune subcentimetric și rari alți constituenți antropici, reprezentând un rezultat al unei acțiuni antropice.

Stratigrafia internă a Cx3, mai simplă decât în cazul Cx1, indică existența a trei momente importante de umplere. Singurul de natură antropică (constituit de US40, US39 și US38, corespunzând caracteristicilor generale primului moment al Cx1 și fiind depozitarul a 99\% din inventarul gropii) este precedat de un moment marcat de prăbușiri de fragmente din pereții gropii (US42 și US41) și succedat de un altul - reprezentat de episoade de umplere naturală - fie prin aceleași prăbușiri, fie prin degradări accentuate ale pereților (uneori și ale sedimentelor exterioare) US36-US31. Și în acest caz, din US38, au fost prelevați șapte litri de sediment, sitați la umed și, apoi, materialul arheologic recuperat.

Ceramica și resturile arheozoologice sunt singurele materiale descoperite şi recuperate. Provin exclusiv ${ }^{8}$ din cuprinsul celor două complexe mai sus descrise. Chiar dacă inventarul Cx3 este mai slab cantitativ, caracteristicile ambelor categorii sunt unitare, dovedind atât o contemporaneitate, cât și manifestări şi comportamente identice.

O analiză a ceramicii din situl de la Mirău a pornit, firește, de la categoriile de pastă identificate macroscopic. Întregul lor a fost analizat și din punct de vedere al provenienței dintr-o zonă sau alta a vasului inițial și din punct de vedere dimensional ${ }^{9}$ (al fragmentării). Am avut în vedere și numărul minim de vase (NMV), precum și pe cel al fragmentelor ceramice, fără îndoială.

În cadrul ansamblului ceramic al Cx1 au fost identificate și definite cinci categorii de pastă, mai jos descrise; materialul este parțial întregibil.

Materialul ceramic descoperit în $\mathrm{Cx} 3$ este foarte fragmentar și în totalitate neîntregibil. Au fost identificate numai două categorii principale de pastă ( $\mathrm{P} 1$ și $\mathrm{P} 2$, prezente și în cadrul ceramicii provenite din Cx1), cu variante nesemnificative - trebuie menționat că în cuprinsul aceluiași fragment ceramic există ușoare diferențe.

Astfel, tipul 1 de pastă (P1) (Fig. 20; Fig. 21/1-3; Fig. 22/1-4; Fig. 23/1; Fig. 26/1-2; Fig. 28/4) este reprezentat de un sediment relativ omogen, cel puțin aparent degresat, dar cu unele goluri, care are în compoziție nisip fin și micá (cel puțin 5\%, dar nu mai mult de 10\%) și rareori, dar numai accidental, pietriș mediu (diam. $4 \mathrm{~mm}$ ). Toate exemplarele inițiale au fost lucrate la roată. Suprafețele exterioare ale pereților vaselor sunt mai ales neteziți îngrijit. Arderea este oxidantă, uneori incompletă. Decorul - rar - este reprezentat de benzi liniare (Fig. 20/4) sau vălurite incizate, în trei cazuri (Fig. 21/1; Fig. 22/2), sau, într-altul, de puncte dreptunghiulare ștanțate cu un obiect din os sau lemn, organizate liniar oblic (cel puțin aparent, au fost și umplute cu pastă albă) și încadrate de benzi incizat-canelate (Fig. 21/3; Fig. 23/1). Faptul că același tip de decor, prezent pe același tip de vas, se regăsește atât în $\mathrm{Cx} 3$, cât și în cele două momente antropice de umplere ale Cx1, este un argument al contemporaneității lor.

Excepție o face un fragment al unui picior de fructieră (?) (Fig. 28/4) al cărui decor principal este constituit de benzi paralele șlefuite. Este și singurul exponent al unei probabile vesele de masă.

În cazul ambelor complexe, o serie de fragmente de funduri de vase păstrează dovezi ale arderii secundare, recipientele fiind în contact direct cu focul (în calitatea lor de vase pentru gătit). În plus, uzura părții lor inferioare denotă o utilizare intensă.

O mențiune specială o necesită un fragment de vas descoperit în primul moment de umplere al Cx1 - este modelat la

\footnotetext{
8 Nu considerăm fragmentele de țiglă care provin de la acoperișurile grajdurilor din perioada comunistă, cele de cărămizi, de metal sau altele asemenea ca pe descoperiri arheologice.

9 Fără a insista, menționăm intervalele de dimensiuni utilizate - dim. 1 (dimensiune maximă $3 \mathrm{~cm}$ ), dim. 2 (dimensiune maximă cuprinsă între 3 și $5 \mathrm{~cm}$ ), dim. 3 (dimensiune maximă peste $5 \mathrm{~cm}$ ).
} 
mână, pasta este mai puțin omogenă; în zona de contact a bazei cu pereții vasului, la interior, sunt amprente digitale succesive care indică acțiunea de presare a lutului moale de la baza pereților pentru modelarea bazei - grosimea celei din urmă este mult inferioară celeilalte. Așadar, construirea vasului nu a început prin individualizarea bazei, ci s-a încheiat cu aceasta (Fig. 26/1-2).

O variantă a acestui tip de pastă (P11) (Fig. 21/4-5; Fig. 23/2; Fig. 24-25; Fig. 26/3; Fig. 27) este foarte omogenă, păstrează degresanții și tratamentul suprafeței interioare, precum și decorul liniar incizat-canelat al tipului anterior de pastă (Fig. 21/4; Fig. 23/2; Fig. 24/2; Fig. 26/3; Fig. 27/1). Diferențele notabile sunt marcate de arderea reducătoroxidantă și prin prezența unei angobe roșu-brun deschis (firesc, pierdută pe alocuri) pe suprafața exterioară. Patru dintre fragmentele ceramice în discuție (reprezentând un NMV =3) au marginile spărturii/rupturii șlefuite, tinzându-se spre o formă generală triunghiulară sau dreptunghiulară (Fig. 21/5; Fig. 27/3-5). Sunt jetoane - unul dintre ele este descoperit în Cx1, US16 (Fig. 21/5), celelalte trei în unitățile stratigrafice ale primului moment de umplere al Cx1 (Fig. 27/3-5).

În cazul acestor tipuri de pastă, numai ulciorul este forma recognoscibilă.

Tipul 2 de pastă (P2) (Fig. 21/6-7; Fig. 22/5-7; Fig. 28/2) include o matrice sedimentară foarte omogenă, cu nisip mediu și mare în compoziție (cca $15 \%$ ), ceea ce conferă spărturii un aspect tăios. Toate exemplarele inițiale au fost lucrate la roată. Suprafețele exterioare ale pereților vaselor sunt îngrijit netezite iar arderea este oxidantă, rareori incompletă. Grosimea pereților vaselor este mult mai mică decât cea a exemplarelor lucrate din primul tip de pastă, iar volumul recipientelor mai mic. Singurul tip de decor păstrat este reprezentat de diferite variante de caneluri/incizii organizate orizontal pe gât și/sau în zona diametrului maxim (Fig. 21/6-7; Fig. 22/5-7; Fig. 28/2). Două fragmente de buză (ale aceluiași vas), descoperite în Cx3, păstrează pete de smalț deteriorat (probabil, verdegalben-brun), la interior (Fig. 22/7).

Ulciorul (de dimensiuni medii și mici) și cana sunt formele confecționate din acest tip de pastă și păstrate.

Tipul 3 de pastă (P3) (Fig. 28/2-3) este foarte omogen, sedimentul, foarte bine degresat, include numai nisip fin (cca 5\%). Toate exemplarele inițiale au fost lucrate la roată. Suprafețele exterioare ale pereților vaselor sunt foarte bine netezite iar arderea este exclusiv oxidantă, uneori și secundară.

Cana pare să fie singura formă pentru care a fost utilizat acest tip de pastă.

Tipul de pastă 4 (P4) reprezentat numai prin 10 fragmente ceramice, descoperite în primul moment de umplere al Cx1, este grosier, individualizat printr-un sediment cu nisip mediu și mare (cca 15\%) și pietriş fin (cel puțin $5 \%$ ), neomogen (având goluri și fisuri). Toate exemplarele inițiale au fost lucrate la roată. Suprafețele exterioare ale pereților vaselor sunt bine netezite iar arderea este mai ales oxidantă. Toate sunt afumate la exterior, putând presupune că acest tip de pastă a fost utilizat numai pentru vase de gătit, menite a fi în contact direct cu focul.

Singura formă construită din acest tip de pastă este ulciorul de mari dimensiuni.

Tabel 1. Tabel cumulativ al ansamblului ceramic de la Mirău.

\begin{tabular}{|c|c|c|c|c|c|c|c|c|c|}
\hline Cx & pastă & NMV & nr. frag. & corp & buză & bază & dim. $\mathbf{1}$ & dim. 2 & dim. 3 \\
\hline 1 inf & $\mathrm{P} 1$ & $1(\mathrm{~V} 4)$ & 1 & 0 & 0 & 1 & 0 & 0 & 1 \\
\hline $1 \mathrm{inf}$ & $\mathrm{P} 1$ & $1(\mathrm{~V} 7)$ & 4 & 3 & 1 & 0 & 0 & 2 & 2 \\
\hline $1 \mathrm{inf}$ & $\mathrm{P} 1$ & $1(\mathrm{~V} 8)$ & 36 & 32 & 0 & 4 & 0 & 18 & 18 \\
\hline $1 \mathrm{inf}$ & $\mathrm{P} 1$ & 15 & 26 & 23 & 0 & 3 & 1 & 13 & 12 \\
\hline $1 \mathrm{sup}$ & $\mathrm{P} 1$ & 5 & 19 & 19 & 0 & 0 & 4 & 7 & 8 \\
\hline \multicolumn{2}{|c|}{ Total P1 } & $\mathbf{2 3}$ & $\mathbf{8 6}$ & $\mathbf{7 7}$ & $\mathbf{1}$ & $\mathbf{8}$ & $\mathbf{5}$ & $\mathbf{4 0}$ & $\mathbf{4 1}$ \\
\hline $1 \mathrm{inf}$ & $\mathrm{P} 11$ & $1(\mathrm{~V} 1)$ & 47 & 44 & 1 & 2 & 16 & 19 & 12 \\
\hline $1 \mathrm{inf}$ & $\mathrm{P} 11$ & $1(\mathrm{~V} 2)$ & 15 & 13 & 1 & 1 & 0 & 6 & 9 \\
\hline $1 \mathrm{inf}$ & $\mathrm{P} 11$ & $1(\mathrm{~V} 3)$ & 14 & 10 & 0 & 4 & 4 & 7 & 3 \\
\hline $1 \mathrm{inf}$ & $\mathrm{P} 11$ & $1(\mathrm{~V} 5)$ & 9 & 8 & 1 & 0 & 0 & 3 & 6 \\
\hline $1 \mathrm{inf}$ & $\mathrm{P} 11$ & $1(\mathrm{~V} 6)$ & 2 & 2 & 0 & 0 & 0 & 0 & 2 \\
\hline $1 \mathrm{inf}$ & $\mathrm{P} 11$ & $1(\mathrm{~V} 11)$ & 2 & 2 & 0 & 0 & 0 & 2 & 0 \\
\hline $1 \mathrm{inf}$ & $\mathrm{P} 11$ & $1(\mathrm{~V} 13)$ & 2 & 2 & 0 & 0 & 0 & 2 & 0 \\
\hline $1 \mathrm{sup}$ & $\mathrm{P} 11$ & 2 & 15 & 14 & 1 & 0 & 3 & 9 & 3 \\
\hline 1 inf & $P 11$ & 2 & 3 & 3 & 0 & 0 & 0 & 3 & 0 \\
\hline
\end{tabular}




\begin{tabular}{|c|c|c|c|c|c|c|c|c|c|}
\hline 1 sup & $P 11$ & 1 & 1 & 1 & 0 & 0 & 0 & 1 & 0 \\
\hline \multicolumn{2}{|c|}{ Total P11 } & 12 & 110 & 99 & 4 & 7 & 23 & 52 & 35 \\
\hline $1 \mathrm{inf}$ & P2 & 1 (V9) & 1 & 0 & 1 & 0 & 0 & 1 & 0 \\
\hline $1 \mathrm{inf}$ & P2 & 6 & 8 & 6 & 0 & 2 & 0 & 4 & 4 \\
\hline 1 sup & $\mathrm{P} 2$ & 6 & 8 & 6 & 2 & 0 & 6 & 1 & 1 \\
\hline \multicolumn{2}{|c|}{ Total P2 } & 13 & 17 & 12 & 3 & 2 & 6 & 6 & 5 \\
\hline $1 \mathrm{inf}$ & $\mathrm{P} 3$ & $1(\mathrm{~V} 10)$ & 1 & 0 & 1 & 0 & 0 & 1 & 0 \\
\hline $1 \mathrm{inf}$ & P3 & $1(\mathrm{~V} 12)$ & 1 & 0 & 1 & 0 & 0 & 1 & 0 \\
\hline \multicolumn{2}{|c|}{ Total P3 } & 2 & 2 & $\mathbf{0}$ & 2 & $\mathbf{0}$ & $\mathbf{0}$ & 2 & $\mathbf{0}$ \\
\hline $1 \mathrm{inf}$ & P4 & 4 & 8 & 6 & 0 & 2 & 2 & 3 & 3 \\
\hline $1 \mathrm{inf}$ & $\mathrm{P} 4$ & 2 & 2 & 2 & 0 & 0 & 0 & 2 & 0 \\
\hline \multicolumn{2}{|c|}{ Total P4 } & 6 & 10 & 8 & $\mathbf{0}$ & 2 & 2 & 5 & 3 \\
\hline \multicolumn{2}{|c|}{ Total Cx1 } & 56 & 225 & 196 & 10 & 19 & 36 & 105 & 84 \\
\hline $\mathrm{Cx} 3$ & $\mathrm{P} 1$ & 26 & 27 & 23 & 1 & 3 & 11 & 9 & 7 \\
\hline $\mathrm{Cx} 3$ & $\mathrm{P} 2$ & 12 & 13 & 10 & 3 & 0 & 5 & 7 & 1 \\
\hline \multicolumn{2}{|c|}{ Total Cx3 } & 38 & 40 & 33 & 4 & 3 & 16 & 16 & 8 \\
\hline
\end{tabular}

(caracterele italice marchează cele patru jetoane descoperite în Cx1)

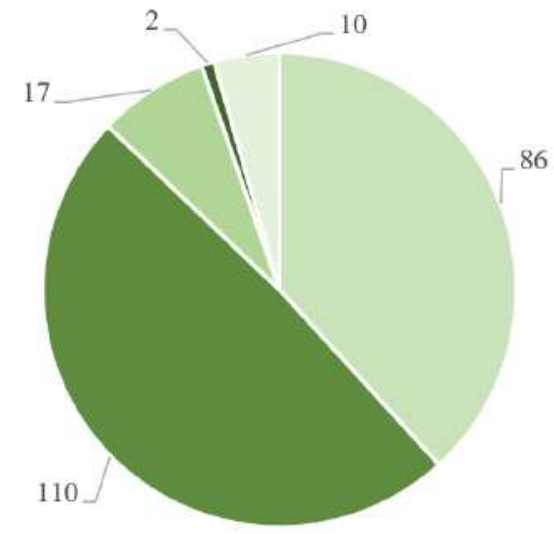

Distribuția fragmentelor ceramice din Cx1 în funcție de tipul de pastă-P1 (86), P11 (110), P2 (17), P3 (2) și P4 (10).

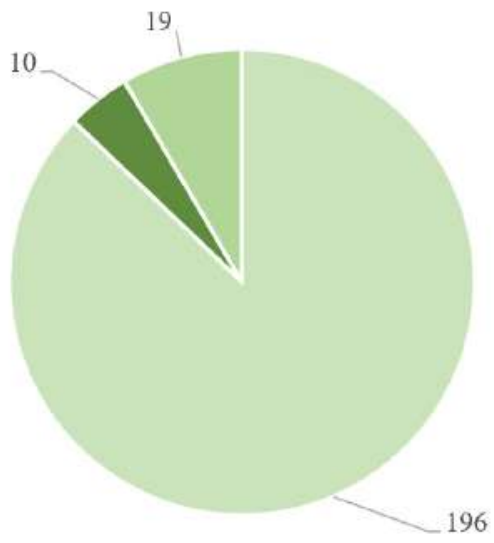

Repartiția fragmentelor ceramice din CxI în funcție de zona de proveniență din vasul inițial - corp (196), buză (10) și bază (19). 


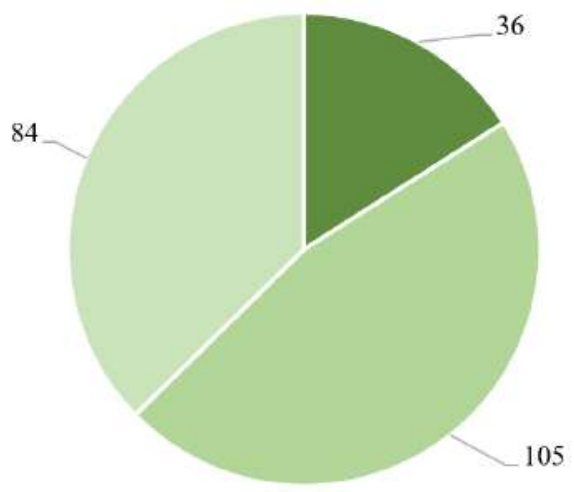

Distribuția fragmentelor ceramice din Cxl în funcție de clasele dimensionale$1-3 \mathrm{~cm}$ (36), $3-5 \mathrm{~cm}$ (105), peste $5 \mathrm{~cm}(84)$.

\section{Discuții}

Deși materialul ceramic nu este prezent în cantitate mare, putem face ${ }^{10} \mathrm{o}$ serie de considerații. Indiferent de tipul de pastă, pereții vaselor sunt mai ales subțiri, ceea ce nu se întâlnește în sec. XVII-XVIII, fiind o caracteristică anterioară - în jurul sec. XVI. Ceramica arsă majoritar oxidant este, de asemenea, caracteristică ansamblelor medievale începând cu sec. XV. În plus, angoba roșu-brun deschis a tipului de pastă P11, ars oxidant, de asemenea, se întâlnește în special în sec. XV, dar şi la începutul celui următor, aceeași datare putând fi atribuită şi decorului cu roată dințată. Așadar, putem data cele două complexe undeva în sec. XVI. Acest reper temporal concordă cu prima atestare documentară a Mirăului, după cum vom evidenția mai jos.

Tipurile dimensionale, prezența nefirească mai mare a fragmentelor de baze față de buze, reprezentarea absolut majoritară a vaselor (preponderent ulcioare) de dimensiuni medii și mari (în defavoarea celor de mici dimensiuni) (Tabel 1), lipsa fragmentelor de farfurii, străchini sau veselă cu funcţionalitate similară, caracteristicile materialului arheozoologic, toate acestea ne determină să presupunem o manipulare mai degrabă secundară a fragmentelor. Pentru că zona cercetată nu păstrează urme de locuire efectivă, nefiind, practic, în interiorul vreunei așezări, este de presupus că materialul arheologic a fost transportat pentru a fi redepozitat în cele două gropi, acțiune necunoscută nouă pentru perioada medievală. Chiar dacă cele două gropi au fost săpate pentru utilizarea sedimentelor - ea însăși o activitate nefirească, extragerea lutului fiind mai facilă din marginea terasei -, ele au fost folosite ulterior pentru redepozitare de deșeuri, inclusiv de resturi a numeroase focuri domestice, însoțite fiind și de resturile unei foarte probabile vetre dezafectate. Din nefericire, cunoaștem foarte puțin despre locuirile rurale medievale din Țara Românească, cu elemente decelate pentru a putea fi comparate.

Importante de menționat sunt atât identitatea/similaritatea ansamblurilor ceramice ale celor două complexe cercetate, chiar având în vedere diferențele cantitative, cât și cea a resturilor scheletice de mamifere și pești și a tratamentului acestora.

Nu uităm a menționa că două fragmente ceramice, descoperite în umplutura $\mathrm{Cx} 1$, având dimensiunea maximă sub $2 \mathrm{~cm}$, ținând cont de caracteristicile fabric-ului, sunt preistorice - cel mai probabil, gumelnițene ${ }^{11}$. Firește, sunt elemente intruzive în complexul respectiv, antrenate ulterior, dar atestă o locuire a zonei din proximitate - cel puțin de scurtă durată - din perioada eneolitică.

Despre perioada medievală a Mirăului există o primă informație clară din secolul al XVI-lea. Un anume Neagu din Mirău cumpăă o parte de moșie (DRH B, vol. V, documentul 167, p. 180). Un fragment al documentului, datat 15 martie 1560, este redat mai jos:

„Moșia Vlăşănul, Mierăul, Stoenești i Desegari ot sud Vlașca.

Adecă eu, Radul ot Glupavi, scris-am zapisul mieu la mână Neagului ot Mirăul, ca să fie de bună credință, să să știe că i-am vândut partea mea de moșie de la Velico de la Padina Mare, partea mea toată (...)”.

Abia la finele secolului al XVIII-lea, așa cum putem sesiza cartografic printr-o sumară analiză a hărții primei ridicări topografice austriece (Fig. 6), Mirăul este individualizat, dar nu ca sat ci ca loc de grădini (așa cum indică verdele

\footnotetext{
10 Mulțumim și aici colegului și prietenului Silviu Oța care ne-a consiliat cu amabilitate.

11 Descoperiri similare - asupra cărora vom reveni cu alte prilejuri - însoțesc majoritatea cercetărilor arheologice preventive de pe traseul magistralei BRUA din județul Giurgiu.
} 
corespondent al unei astfel de prezențe, în legenda hărții primei ridicări topografice austriece - https://www.arcanum. hu/media/uploads/mapire/legend/ firstsurvey. pdf).

Primele construcții gospodărești sunt reținute pe harta celei de-a doua ridicări topografice austriece (Fig. 7), grupate pe firul Văii Râcu, nucleul dezvoltându-se apoi, mai cu seamă, spre sud, de-a lungul văii sus numite Planul Director de Tragere (Fig. 8) - și nicidecum spre est, unde este amplasat situl cercetat preventiv.

Primele mențiuni scrise în legătură cu satele din proximitatea stațiunii arheologice privesc secolul al XIX-lea. Tangârul și Stoeneștiul erau comune, iar Mirăul doar cătun, toate arondate plasei Câlniștea din Județul Vlașca (astăzi Giurgiu) $^{12}$.

Despre cătunul Mirău aflăm că la 1860 au fost împroprietăriți 74 de clăcași (cu siguranță, locuințele lor fiind figurate pe harta celei de-a doua ridicări topografice austriece) cu 310 ha - anterior localitatea aparținuse mănăstirii Sarindarul - fără îndoială, grădinile, mai sus menționate, de pe Harta Specht, corespund acestei stări de fapt.

Revenind pentru a încheia aceste considerații, este de presupus, fără îndoială, că ceea ce rețin documentele consultate privind realitătile din sec. al XVIII-lea trebuie să se fi petrecut și anterior, un nucleu de populație rurală medievală trebuind să fi existat în zona Mirăului, cu atât mai mult cu cât exista un Neagu ,din Mirău”.

\section{Fauna medievală}

Studiul arheozoologic a fost realizat pe un număr redus de resturi faunistice $(N R=528)$ care provin din cele două complexe arheologice ( $\mathrm{Cx} 1$ și Cx3) care au fost încadrate în perioada secolului al XVI-lea. Pentru Muntenia, eșantionul faunistic de la Mirău este printre puținele studiate dacă avem în vedere că în această regiune mai există o singură altă aşezare, cea de la Oraşul de Floci, relativ contemporană (secolele XV-XVI), care a fost analizată din punct de vedere arheozoologic ${ }^{13}$

Ceea ce este extrem de interesant la acest eșantion faunistic este faptul că o parte din sedimentul arheologic a fost cernut sub jet de apă, acest lucru petrecându-se în condițiile unei cercetări preventive. Astfel, din Cx1 s-au sitat 601 de sediment, în timp ce din Cx3 doar șapte. În strînsă legătură cu cantitatea de material sitat și triat (dar şi cu mărimea/dimensiunile acestor complexe) este și numărul de resturi faunistice descoperite. De exemplu în Cx1 s-au identificat 495 resturi, iar în Cx3, doar 33 resturi, fauna totalizând 528 resturi (Tabel 2).

Avantajele şi dezavantajele acestei metode de prelevare prin sitare au fost prezentate și cu altă ocazie (Popovici et alii, 2002) de aceea nu vom insista prea mult asupra acestui subiect. Cert este că prin cernerea sedimentului putem să avem la dispoziție tot conținutul în resturi faunistice (şi nu numai) al acestor complexe ceea ce ne permite reconstituirea economiei alimentare de origine animalieră. Astfel în material s-au identificat pești, păsări și mamifere (Tabel 2). Cele mai numeroase sunt resturile de pește $(64,96 \%)$ dar ele nu reprezintă decât $1,54 \%$ din masa totală, mamiferele fiind dominante $(97,66 \%)$ in acest sens (Tabel 2).

Din punct de vedere al metodologiei arheozoologice, s-au utilizat metodele prezentate în lucrările lui Radu ${ }^{14}$ pentru pești și Bălășescu ${ }^{15}$ pentru mamifere. În cazul păsărilor s-a utilizat colecția de comparație pentru determinări şi datele din Von den Driesch ${ }^{16}$ pentru măsurători. Repartiția pe specii și elemente anatomice a mamiferelor identificate la Mirău este prezentată în Anexa 1. Datele biometrice ale mamiferelor s-au realizat conform normelor internaționale elaborate de Von den Driesch ${ }^{17}$ și sunt reunite în Anexa 2.

Tabel 2. Repartiția numerică și procentuală a numărului de resturi (NR) și a greutății lor (G, în grame) pentru cele două complexe analizate (Cx1 și Cx3) de la Mirău.

\begin{tabular}{|l|c|c|c|c|c|c|c|c|c|c|c|c|}
\cline { 2 - 16 } \multicolumn{1}{c|}{} & \multicolumn{4}{c|}{ Complex 1 } & \multicolumn{3}{c|}{ Complex 3 } & \multicolumn{4}{c|}{ Total } \\
\hline Taxon & \multicolumn{3}{c|}{ NR } & \multicolumn{2}{c|}{ G } & \multicolumn{2}{c|}{ NR } & \multicolumn{3}{c|}{ G } & \multicolumn{3}{c|}{ NR } & G \\
\hline Pisces & 332 & 67,07 & 42,78 & 1,84 & 11 & 33,33 & 0,28 & 0,06 & 343 & 64,96 & 43,06 & 1,54 \\
\hline Aves & 17 & 3,43 & 21,47 & 0,93 & 1 & 3,03 & 0,80 & 0,17 & 18 & 3,41 & 22,27 & 0,80 \\
\hline Mammalia & 146 & 29,50 & 2256,00 & 97,23 & 21 & 63,64 & 472,00 & 99,77 & 167 & 31,63 & 2728 & 97,66 \\
\hline Total & 495 & 100 & 2320,25 & 100 & 33 & 100 & 473,08 & 100 & 528 & 100,00 & 2793,3 & 100,00 \\
\hline
\end{tabular}

\footnotetext{
Lahovari et al. 1901, 347; Lahovari et al. 1902, 472, 544.

Bejenaru 2006, 46, tabel 7.

Radu 2011.

Bălășescu 2014.

Driesch 1976.

7 Driesch 1976.
} 
Fauna studiată prezintă toate caracteristicile unor deșeuri menajere și anume o fragmentaritate accentuată, urme de tăiere (descărnare și dezarticulare) și de ardere.

\section{Prezentarea materialului faunistic}

Pești. Au fost identificate 343 resturi de pește (Tabel 3). Acestea au aparținut câtorva specii de apă dulce (Anexa 3.1-5) precum știuca (Esox lucius), plătica (Abramis brama), crapul (Cyprinus carpio), somnul (Silurus glanis) și şalăul (Sander lucioperca).

Știuca (Esox lucius). Doar cinci resturi provin de la acest pește dintre care majoritatea sunt vertebre (una e calcinată) dar și un cleitrum destul de bine conservat. Acesta din urmă provine de la un individ de talie medie de $0,6 \mathrm{~m}$ lungime totală $(\mathrm{Lt})$ și $1,6 \mathrm{~kg}$.

Plătica (Abramis brama). Au fost identificate resturi ce provin de la cel puțin patru indivizi. Dimensiunile acestora sunt mici și medii cuprinse între $0,21-0,33 \mathrm{~m} \mathrm{Lt}(0,15-0,39 \mathrm{~kg})$. Masa totală a celor patru indivizi era de circa 1,1 $\mathrm{kg}$.

Crapul (Cyprinus carpio) este a doua specie cu o prezență consistentă de resturi scheletice. Aceste fragmente provin de la un număr minim de patru indivizi ce au avut dimensiuni în general mici în cazul a trei dintre ei $(0,25$ $0,35 \mathrm{~m} \mathrm{Lt} \mathrm{și} 0,25-0,6 \mathrm{~kg}$ ) și mare în cazul celui de-al patrulea de circa $0,5 \mathrm{~m} \mathrm{Lt}$ ( $3 \mathrm{~kg}$ ). Masa totală a celor patru indivizi era de circa $4,17 \mathrm{~kg}$.

Resturi disparate ce provin din zona capului au fost identificate ca aparținând șalăului (Sander lucioperca): un individ de talie mică de $0,3 \mathrm{~m} \mathrm{Lt}(0,3 \mathrm{~kg})$ și un dentar ce a fost secționat antero-posterior de la un individ de dimensiuni medii de $0,6 \mathrm{~m} \mathrm{Lt}(1,8 \mathrm{~kg})$.

Somnul (Silurus glanis) este şi el prezent cu resturi disparate de la nivelul capului dar şi cu o vertebră care a aparținut unui individ de talie mică de $0,7 \mathrm{~m} \mathrm{Lt}(2,5 \mathrm{~kg})$.

Tabel 3. Repartiția resturilor de pești şi păsări

și a greutății lor (în grame) pentru cele două complexe analizate (Cx1 şi Cx3) de la Mirău.

\begin{tabular}{|l|c|c|c|c|}
\cline { 2 - 5 } \multicolumn{1}{c|}{} & \multicolumn{2}{c|}{ Complex 1 } & \multicolumn{2}{c|}{ Complex 3 } \\
\hline Taxon & NR & G & NR & G \\
\hline Esox lucius & 5 & 1,45 & & \\
\hline Abramis brama & 35 & 4,41 & & \\
\hline Cyprinus carpio & 29 & 5,94 & & \\
\hline Cyprinidae & 87 & 4,56 & & \\
\hline Sander lucioperca & 3 & 0,49 & & \\
\hline Silurus glanis & 5 & 2,53 & & \\
\hline Pisces ind. & 168 & 23,4 & 11 & 0,28 \\
\hline Total Pisces & $\mathbf{3 3 2}$ & $\mathbf{4 2 , 7 8}$ & $\mathbf{1 1}$ & $\mathbf{0 , 2 8}$ \\
\hline Gallus domesticus & 4 & 8,75 & & \\
\hline Anser sp. & 1 & 6,8 & & \\
\hline Aves ind. & 12 & 5,92 & 1 & 0,8 \\
\hline Total Aves & $\mathbf{1 7}$ & $\mathbf{2 1 , 4 7}$ & $\mathbf{1}$ & $\mathbf{0 , 8}$ \\
\hline
\end{tabular}

Păsări. În cele două complexe sunt prezente fragmente de coji de ouă (în Tabel 3 au fost notate ca un fragment) ce provin de la păsări (Anexa 3.6) care deocamdată din lipsa unei colecții de referință nu au putut fi determinate taxonomic. Resturile scheletale aparținând păsărilor au fost identificate doar în $\mathrm{Cx} 1$. Acestea au aparținut găinii (Gallus domesticus) și gâsștei (Anser sp.). De la găină sunt prezente resturi de la membrele inferioare. Două fragmente de tibio-tars prezintă os medular și provin de la o femelă (Anexa 3.7). Osul medular este o rezervă de calciu utilizată pe perioada de depunere a ouălelor ${ }^{18}$. Datele biometrice au putut fi culese doar pentru partea distală $(B d=9,6 \mathrm{~mm}, \mathrm{Dd}=10,2 \mathrm{~mm})$. Un alt os de găină întreg, tarso-metatarsul, ne-a permis prelevarea tuturor măsurătorilor ( $\mathrm{GL}=86,7 ; \mathrm{Bp}=15,9 ; \mathrm{SC}=8,1 ; \mathrm{Bd}=16$; în $\mathrm{mm})$. Acesta are dezvoltat un pinten osos și provine de la un mascul. De la gâscă am identificat un humerus ros la nivelul epifizelor (Anexa 3.8) care a aparținut unui individ juvenil (dimensiunile sunt apropiate de cele ale unui adult dar osul este poros). În $\mathrm{Cx} 1$ au mai fost identificate 11 resturi fragmentare ce pot fi atribuite păsărilor.

$18 \quad$ Lentacker and van Neer 1996. 
Mamiferele sunt reprezentate prin 167 de resturi care cântăresc 2728 g. Dintre acestea au fost determinate taxonomic 116 resturi $(69,5 \%)$ care au o greutate de $2497 \mathrm{~g}(91,5 \%)$ (Tabel 4). În material s-au identificat următoarele specii, exclusiv domestice: vita (Bos taurus), oaia (Ovis aries), porcul (Sus domesticus), câinele (Canis familiaris) și calul (Equus caballus) (Anexa 3.9- 3.14). Este posibil ca în cadrul spectrului faunistic să existe și capra (Capra hircus) dar aceasta nu a fost identificată de o manieră precisă în cadrul grupului de ovicaprine (Ovis aries/Capra hircus) indeterminabile (Tabel 4).

Tabel 4. Repartiția numerică şi procentuală a numărului de resturi (NR), greutății (G) şi numărului minim de indivizi (NMI) a faunei de mamifere descoperite la Mirău.

\begin{tabular}{|l|c|c|c|c|c|c|c|c|c|c|c|c|}
\cline { 2 - 15 } \multicolumn{1}{c|}{} & \multicolumn{3}{c|}{ Complex 1 } & \multicolumn{3}{c|}{ Complex 3 } & \multicolumn{3}{c|}{ TOTAL } & \multicolumn{3}{c|}{ TOTAL \% } \\
\hline SPECIA & NR & G & NMI & NR & G & NMI & NR & G & NMI & NR & G & NMI \\
\hline Bos taurus & 72 & 1762 & 5 & 8 & 394 & 2 & 80 & 2156 & 7 & 68,97 & 86,34 & 46,67 \\
\hline Ovis aries & 1 & 33 & 1 & 1 & 12 & 1 & 2 & 45 & 2 & 1,72 & 1,80 & 13,33 \\
\hline ovicaprine & 20 & 96 & 1 & & & & 20 & 96 & 1 & 17,24 & 3,84 & 6,67 \\
\hline Sus domesticus & 9 & 104 & 1 & 3 & 47 & 2 & 12 & 151 & 3 & 10,34 & 6,05 & 20,00 \\
\hline Equus caballus & 1 & 44 & 1 & & & & 1 & 44 & 1 & 0,86 & 1,76 & 6,67 \\
\hline Canis familiarus & 1 & 5 & 1 & & & & 1 & 5 & 1 & 0,86 & 0,20 & 6,67 \\
\hline Total determinate & $\mathbf{1 0 4}$ & $\mathbf{2 0 4 4}$ & $\mathbf{1 0}$ & $\mathbf{1 2}$ & $\mathbf{4 5 3}$ & $\mathbf{5}$ & $\mathbf{1 1 6}$ & $\mathbf{2 4 9 7}$ & $\mathbf{1 5}$ & $\mathbf{1 0 0 , 0}$ & $\mathbf{1 0 0 , 0}$ & $\mathbf{1 0 0 , 0}$ \\
\hline indet talie mare & 32 & 200 & & 4 & 15 & & 36 & 215 & & & & \\
\hline indet talie medie & 10 & 12 & & 5 & 4 & & 15 & 16 & & & & \\
\hline TOTAL & $\mathbf{1 4 6}$ & $\mathbf{2 2 5 6}$ & $\mathbf{1 0}$ & $\mathbf{2 1}$ & $\mathbf{4 7 2}$ & $\mathbf{5}$ & $\mathbf{1 6 7}$ & $\mathbf{2 7 2 8}$ & $\mathbf{1 5}$ & & & \\
\hline
\end{tabular}

Cx1, cu 146 de resturi (87,4\%), este mult mai bogat decât Cx3 în care s-au identificat doar 21 de fragmente (12,6\%). În strânsă relație cu cantitatea de material este și numărul de specii și indivizi identificați. Astfel în Cx1 s-au determinat cinci taxoni care au furnizat 10 indivizi, iar în $\mathrm{Cx} 3$ avem trei taxoni de la cinci indivizi.

În Cx1 s-au identificat 72 resturi de vită care provin de la cinci indivizi (un juvenil, trei adulți de 3,5-4 ani și un adult bătrân); 20 de resturi de ovicaprine care provin de la cel puțin un individ de circa 4-6 ani; o mandibulă de oaie de la un individ în vârstă de 2-4 ani (Anexa 3.12); nouă resturi de porc de la un juvenil de circa 8-12 luni; un femur proximal de cal de la un individ adult (Anexa 3.14); un maxilar de câine ce sugerează un individ juvenil de 4-6 luni. În Cx3 se observă aceași predominare a resturilor de bovine care provin de la doi indivizi (un juvenil și un adult de 6,5-9 ani); un astragal de oaie; trei resturi de porc care atestă cel puțin doi indivizi (un juvenil și un subadult de 16-18 luni).

La nivelul întregului material arheozoologic, resturile de bovine predomină ca NR $(69 \%), G(86,3 \%)$ şi număr minim de indivizi (46,7\%) (Tabel 5). Locul doi, la mare distanță, este disputat de către ovicaprine și porcine. Astfel ovicaprinele depășesc porcinele ca NR (19\% față de 10,3\%), sunt la egalitate ca NMI (20\%), în timp ce ca G, porcinele se situează cu puțin înaintea ovicaprinelor (6\% la 5,6\%) (Tabel 5). Ponderea calului și a câinelui este

Tabel 5. Distribuția procentuală ca număr de resturi (NR), greutate (G) şi număr minim de indivizi (NMI) a faunei de mamifere de la Mirău.

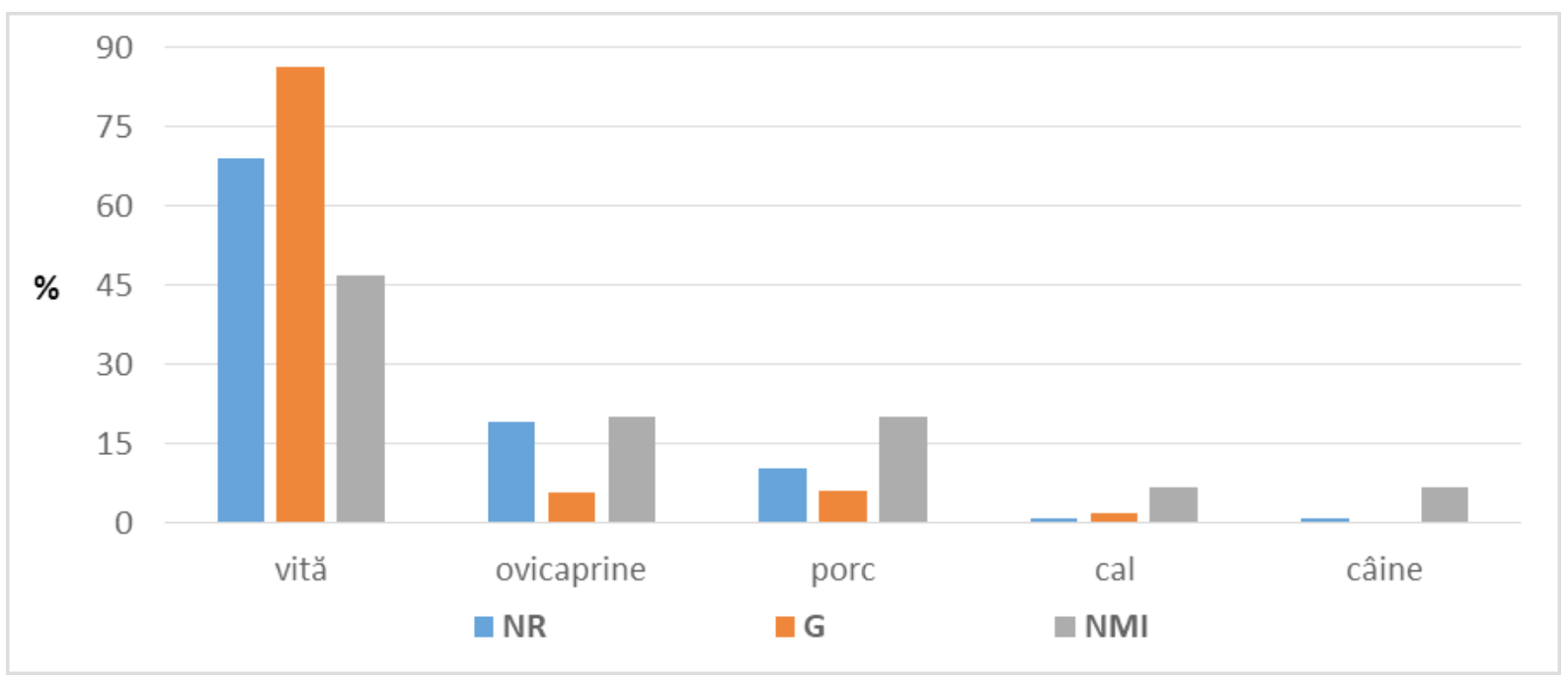


extrem de redusă (sub 1-2\% ca NR și G și sub 7\% ca NMI), dar ceea ce este extrem de interesant este faptul că Equus caballus era consumat, dovadă fiind o urmă de tăiere grosieră identificată pe un col femural.

$\mathrm{Cu}$ toate că eșantionul este relativ redus numeric ca NMI (doar 15 indivizi prezumați) vom încerca reconstituirea economiei alimentare a acestei comunităţi rurale medievale. Pe baza vârstelor de sacrificare ale bovinelor se observă că toate clasele de vârstă sunt prezente, dar predomină adulții tineri (trei) şi juvenilii (doi) ceea ce ar sugera o exploatare mixtă pentru carne și lapte. Existența unor animale mai în vârstă dar şi patologiile observate la nivelul falangelor 1 și $2^{19}$ sugerează și utilizarea acestor animale la tracțiune, într-o manieră intensivă.

Vârstele ovicaprinelor ar sugera o exploatare mai ales pentru produsele secundare, lapte şi lână. Porcul este exploatat mai ales pentru carne, vârstele animalelor fiind relativ tinere, probabil acestea fiind tăiate sezonier, mai ales în sezonul rece.

Datele biometrice sunt extrem de puține (Anexa 2) și ele au fost efectuate mai ales pe oase care în general au dimensiuni reduse (falange, astragale) şi care nu a fost fragmentate în procesul de preparare a hranei. Eşantionul redus nu ne permite să caracterizăm de o manieră pertinentă aceste animale din punct de vedere biometric. Astfel la bovine putem remarca o variație dimensională foarte mare a astragalelor (Anexa 3.10) şi a falangelor (Anexa 3.11) datorată în principal dimorfismului sexual (mascul / femelă / posibil castrat). Pe baza unor astragale întregi ${ }^{20}$ s-a putut calcula talia la oaie $(67,57 \mathrm{~cm}$ - indice Teichert) și la porc $(78,7 \mathrm{~cm}$ - indice Teichert, Anexa 3.13$)$. În cazul oii, valoarea este superioară mediei animalelor de la Piua Petrii ${ }^{21}$.

Materialul deși redus numeric ne permite totuși evidențierea unor observații legate de alimentația locuitorilor din această așezare rurală din Câmpia Română. Astfel, după starea de conservare a oaselor se observă că o parte din acestea au fost în contact cu surse de foc, unele fragmente de pește fiind calcinate și distorsionate. O altă parte este arsă parțial (zone de culoare maron) probabil ca rezultat al procesului de preparare al hranei. Alte resturi însă nu au urme de ardere cum ar fi cazul resturilor de mamifere, păsări și a unora de pește, dar și al cojilor de ouă. Aceste informații ar putea fi în legătura directă cu procesul de preparare a hranei care probabil s-a desfășurat pe parcursul a mai multor etape (sau zile), complexele funcționând ca o zonă de deșeuri.

Din punct de vedere al resturilor prezente în cazul peștilor, mare parte din acestea provin din zona capului sau al înotătoarelor (73\%). Dintre vertebre, cele caudale sunt mai numeroase, iar cele precaudale sunt deficitare (doar nouă) mai ales în cazul ciprinidelor (crap și plătica) prezente cu un număr minim de opt indivizi (care ar fi avut circa 180 vertebre precaudale). Aceste date ne arată că, cel puțin pentru ciprinide, resturile pot fi rezultate atât din procesul de preparare ca deșeuri (înlăturarea capului și a coloanei vertebrale) cât și ca resturi culinare dacă ne gândim că pot proveni de la fierturi unde sunt folosite mai ales tranșele de la cap și coadă. În cazul păsărilor, oasele identificate sunt în mare parte purtătoare de mușchi și pot fi de asemenea deșeuri culinare (roaderea epifizelor distale).

Câteva elemente din această analiză ne pot indica date de sezonalitate. Astfel peștii în general pot fi capturați în perioada estivală, iar dacă adăugăm și prezența cojilor de ouă, a femelei de găină care era ouătoare în momentul sacrificării, dar și a juvenilului de gâscă putem asocia toate aceste resturi ca fiind acumulate în perioada de vară cel târziu până în luna august.

Concluzionând, în cadrul economiei animaliere de la Mirău se creșteau o serie de animale domestice, printre acestea bovinele fiind predominate, urmate de ovicaprine și porcine care îşi dispută locul doi. Bovinele erau exploatate de o manieră mixtă (carne și lapte), dar nu trebuie omisă nici contribuția acestora la tracțiune (ca forță de muncă), în timp ce ovicaprinele erau crescute pentru produsele lor secundare (lapte și lână). Remarcăm consumul alimentar al calului (hipofagia) care probabil era ocazional. Acest fenomen este întâlnit de o manieră izolată în evul mediu românesc în ciuda interdicțiilor religioase, având în vedere că încă din secolul al VIII-lea, papa Grigore III interzice creștinătății consumul acestei cărni care era asociată cu păgânismul. În cazul de la Mirău ne putem gândi fie la un moment de criză alimentară, fie la valorificarea în alimentație a animalelor bătrâne/accidentate.

O comparaţie cu situl de la Piua Petrii ${ }^{22}$ ne arată o serie de similitudini, în sensul că bovinele predomină ca NR, acestea fiind urmate de ovicaprine și porcine.

\section{Concluzii}

Deși redus, ansamblul materialului arheologic descoperit la Mirău - ceramic și arheozoologic -, a permis, pe de o parte, datarea acestui tip de sit inedit, în secolul al XVI-lea, iar pe de alta a relevat o serie de trăsături specifice.

\footnotetext{
Bartosiewicz et al. 1997.

Udrescu et al. 1999.

Bejenaru 2003, 233, tabel 46.

Bejenaru 2003, 233, tabel 46.
} 
Așa cum am menţionat, cele două complexe medievale nu se află efectiv în interiorul vreunei aşezări. De aceea, este de presupus că materialul arheologic a fost transportat pentru a fi redepozitat în cele două gropi, acțiune necunoscută nouă pentru perioada medievală. În sine, inventarul recuperat are toate caracteristicile unor deșeuri menajere. Tipul vaselor, în general, gradul de fragmentare a ceramicii, resturile numeroaselor focuri domestice însoțite și de resturile unei foarte probabile vetre dezafectate, precum și trăsăturile materialului osos indică acest lucru. Toate laolaltă par să marcheze și o acțiune permanentă, deși de scurtă durată, de ascundere a urmelor lăsate de o serie de activități cel puțin aparent legate de pregătirea hranei (dar și de obținerea ei). Dacă prezența ceramicii din clasele dimensionale mari sau a resturilor osoase facil selectabile pentru transport ar putea fi cumva explicată, deși cu greu vizualizăm curățenii generale în secolul al XVI-lea, toate celelalte resturi strict de natură antropică sunt, în sine, în primul rând, dificil de a fi recuperate pentru transport.

Informațiile de natură stratigrafică sunt pe deplin completate de cele arheozoologice. Lăsând deoparte rațiunile pentru care au fost săpate cele două gropi - estimăm că momentul principal de umplere antropică, plasat cronologic la scurt timp după excavare, s-a petrecut în sezonul cald, pentru ca, momentul principal de umplere naturală să aparțină sezonului rece. Revenirea antropică sesizată în cazul Cx1 se va fi petrecut la sfârșitul acestui sezon rece sau la debutul sezonului cald următor, dar nu are absolut niciuna din caracteristicile anterioare.

Din păcate, cunoaștem foarte puțin despre locuirile rurale medievale din Țara Românească, cu elemente decelate pentru a putea fi comparate.

\section{BiBLIOGRAFIE}

Bartosiewicz, L., Van Neer, W. şi And Lentacker, A., 1997. Draught cattle: their osteological identification and history, Annales Sciences Zoologiques, Musée Royal de l'Afrique Centrale, Tervuren, vol. 281, 147 p.

Bălăşescu, A., 2014. Arheozoologia neo-eneoliticului de pe Valea Teleormanului, Muzeul Naţional de Istorie a României, Colecția Muzeului Național, Seria Cercetări Puridisciplinare, XIV, Editura Mega, Cluj Napoca.

Bejenaru, L., 2003. Arheozoologia spațiului românesc medieval, Editura Universităţii “Alexandru Ioan Cuza", Iaşi, $252 \mathrm{p}$.

C. Bem, A. Asăndulesei, C. Bem, F.A. Tencariu, V. Cotiugă şi Şt. Caliniuc, Identity in diversity: photogrammetry, 3D laser scanning and magnetometric analysis of Gumelniţa tells from Muntenia (Romania), V. Cotiugă, Șt. Caliniuc (Eds.) Interdisciplinarity Research in Archaeology. Proceedings of the First Arheoinvest Congress, 10-11 June 2011, Iaşi, Romania, BAR International Series 2433, Archaeopress, Oxford, p. 19-36.

D. Berciu, Săpăturile de la Tangâru (1934). Raport preliminar, Buletinul Muzeului Judeţean Vlaşca "Teohari Antonescu” 1, Bucureşti, 1935, p. 1-55 (extras).

D. Berciu, Prime consideraţii asupra neoliticului din Valea Dunării Inferioare în legătură cu descoperirile din judeţul Vlaşca, Buletinul Muzeului Județean Vlaşca “Teohari Antonescu” 2, Bucureşti, 1937, p. 31-105.

D. Berciu, Săpăturile arheologice de la Tangâru (r. Giurgiu, reg. București), Materiale şi Cercetări Arheologice 5, Bucureşti, 1959, p.143-154.

D. Berciu, Săpăturile arheologice de la Tangâru şi Petru Rareş, in Materiale şi Cercetări Arheologice 6, Bucureşti, 1959, p. 137-146.

D. Berciu, Contribuţii la problemele neoliticului în România în lumina noilor cercetări, Ed. Academiei, Bucureşti, $1961,593 \mathrm{p}$.

Driesch, A. Von den, 1976: guide to the measurement of animal bones from archaeological sites, Peabody Museum Bulletin, 1, Harvard University, $137 \mathrm{p}$

George Ioan Lahovari, C.I. Brătianu, Grigore C. Tocilescu, Marele Dicționar Geografic al României, Stab. Grafic J. V. Soceco, București, vol IV, 1901.

George Ioan Lahovari, C.I. Brătianu, Grigore C. Tocilescu, Marele Dicționar Geografic al României, Stab. Grafic J. V. Soceco, București, vol V, 1902.

Lentacker, A., van Neer W. 1996: Bird remains from two sites on the Red Sea coast and some observations on medullary bone. International Journal of Osteoarchaeology 6, p. 489-96.

Popovici, D., Bălăşescu, A., Haită, C., Radu, V., Tomescu, A.M.F., Tomescu, I., 2002: Cercetarea arheologică pluridisciplinară. Concepte, metode şi tehnici, Biblioteca Muzeului Naţional, Seria Cercetări Pluridisciplinare, 3, 
Cetatea de Scaun Târgoviş̧e, 78 p şi 11 Radu, V., Le Néolithique de la Roumanie Méridionale: Exploitation des ressources aquatiques dans les cultures Boian et Gumelniţa, Sarrebruck, Editions Universitaires Européennes.

C. Schuster, T. Popa, Mironești. I. Locuri, cercetări arheologice, monumente și personaje istorice, Bibliotheca Musei Giurgiuvensis, III, Giurgiu, 2008.

C. Schuster, T. Popa, Fingerprints of the Past in the Giurgiu County. The Bronze Age, Bibliotheca Musei Giurgiuvensis, V, Giurgiu, 2010.

SC. Schuster, T. Popa, V. Barbu, Cercetări arheologice în bazinul Argeșului (județul Giurgiu), Bibliotheca Musei Giurgiuvensis, VI, Giurgiu, 2012.

Nicolae Stoicescu, Bibliografia localităților și monumentelor feudale din România. I- Țara Românească (Muntenia, Oltenia și Dobrogea), Vol. 2, M-Z, indici, Mitropolia Olteniei, 1970.

Udrescu, M., Bejenaru, L., Hrişcu, C., 1999: Introducere în arheozoologie, Editura Corson, Iaşi.

CĂTĂLIN BEM

TBL Grup

catalin.bem@tblgrup.ro

ADRIAN VLADU

TBL Grup

vladu.adrian@gmail.com

ADRIAN BĂLĂȘESCU

Institutul de Arheologie "Vasile Pârvan" București abalasescu2005@yahoo.fr

VALENTIN RADU

Muzeul Naţional de Istorie a României radu valentin@hotmail.com 


\section{LIST OF ILLUSTRATIONS}

Fig. 1. Location of the area of interest - Mirău (Giurgiu County).

Fig. 2. Location of Mirău site through the main survey section from march 2020 (marked by two extreme points with ST70 coordinates). The red oval marking the area belonging to the stables demolished in the 80 's of the previous century.

Fig. 3. Location of the Mirău site on the ortophotomap.

Fig. 4. Geologic map (1) of the area belonging to the Mirău site; 2. Geologic map's legend. (http://www.geospatial.org/download/harta-geologica-a-romaniei-scara-1-200-000).

Fig. 5. Mirău site. View from the excavation site upon the aber of Câlniștei river with Râcu Valley (photo Adrian Vladu).

Fig. 6. Mirău site. The first Austrian topographic survey (Specht).

Fig. 7. Mirău site. The second Austrian topographic survey.

Fig. 8. Mirău site. Planul Director de Tragere (sheet 4140, Pângălești).

Fig. 9. Mirău site. Arial view from the west (in the foreground - the ruins of two stables built in the communist era) (photo Cătălin Borangic).

Fig. 10. Mirău site. Stratigraphic detail (the designations have thier discription in the text; the marked limits do not represent a drawing made from a photograph, they are ment to further highlight the stratigraphic situation) - one can easily notice the presence of contemporary materials (highlighted using white outlines).

Fig. 11. Main western profile and the plan of the surveyed section (the designations have their discription in the text).

Fig. 12. Mirău site. Cx1. Plan (1) and profile (2) (the designations have their description in the text). The scale is 1:20. Legend: $\mathrm{x}$-bone fragment, -pottery fragment).

Fig. 13. Mirău site. Negative profile (CD) of $\mathrm{Cx} 1$.

Fig. 14. Mirău site. Cx1 - top view (after finishing the survey) (photo Cătălin Bem).

Fig. 15. Mirău site. $\mathrm{Cx} 1$ - detail of the main profile from the area of the first stratigraphical units accumulated in the pit (the designations have their description in the text) (photo Cătălin Bem).

Fig. 16. Mirău site. Cx3. Plan (1) and profile (2) (the designations have their description in the text). Scale 1:20.

Fig. 17. Mirău site. Negative profile (CD) of $\mathrm{Cx} 3$.

Fig. 18. Mirău site. Cx3 - top view (after finishing the survey) (photo Adrian Vladu).

Fig. 19. Mirău site. $\mathrm{Cx} 3$ - profile detail (photo Adrian Vladu).

Fig. 20. Mirău site. Pottery, paste type 1 (P1). 1-2. Cx1, SU16; 3. Cx1 (first stratigraphical moment), vessel 8; 4. Cx1 (first stratigraphical moment), vessel 7.

Fig. 21. Mirău site. Cx1 (SU16). Pottery fragments (1-4, 6-7) and token (5). 1-3. Paste type 1 (P1); 4-5. Paste type 11 (P11); 6-7. Paste type 2 (P2).

Fig. 22. Mirău site. Cx3. Pottery fragments. 1-4. Paste type 1 (P1); 5-7. Paste type 2 (P2).

Fig. 23. Mirău site. Pottery. 1. Cx1 (first stratigraphical moment), paste type 1 (P1), vessel 8; 2. Cx1, SU16, paste type 11 (P11).

Fig. 24. Mirău site. Pottery. Cx1 (first stratigraphical moment), paste type 11 (P11). 1. Vessel 1; 2. Vessel 2; 3. Vessel 3 .

Fig. 25. Mirău site. Pottery. Cx1 (first stratigraphical moment), paste type 11 (P11), Vessel 1.

Fig. 26. Mirău site. Pottery. 1. Cx1 (first stratigraphical moment), paste type 1 (P1), Vessel 4 (2. Interior detail); 3. Cx1 lower part, paste type 11 (P11), Vessel 6.

Fig. 27. Mirău site. Pottery Cx1 (first stratigraphical moment), paste type 11 (P11). 1. Vessel 2; 2. Vessel 5; 3-5. Tokens manufactured from pottery fragments.

Fig. 28. Mirău site. Pottery $\mathrm{Cx} 1$ (first stratigraphical moment). 1. Paste type 2 (P2); 2-3. Paste type 3 (P3); 4. Paste type $1(\mathrm{P} 1)$. 
Anexa 1. Repartiția pe specii și elemente anatomice a materialului faunistic de la Mirău.

\begin{tabular}{|c|c|c|c|c|c|c|c|c|c|}
\hline & \multicolumn{5}{|c|}{ Complex 1} & \multirow[b]{2}{*}{$\frac{n}{\frac{n}{5}}$} & \multicolumn{3}{|c|}{ Complex 3} \\
\hline ELEMENT ANATOMIC/ SPECIE & $\begin{array}{l}\tilde{s} \\
\vdots \\
0 \\
\tilde{0} \\
0\end{array}$ & 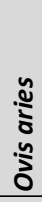 & 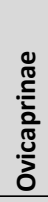 & 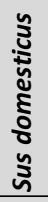 & 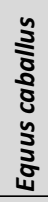 & & 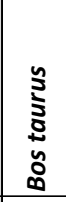 & 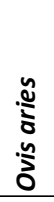 & 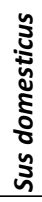 \\
\hline Neurocranium & 1 & & & & & & 1 & & \\
\hline Viscerocranium & 7 & & & & & 1 & 2 & & \\
\hline Dentes sup. & & & 1 & & & & & & \\
\hline Mandibula & 19 & 1 & & & & & & & 1 \\
\hline Dentes inf. & 7 & & & 3 & & & & & \\
\hline Hyoid & 1 & & & & & & & & \\
\hline Costae & 6 & & 10 & 2 & & & 1 & & \\
\hline Scapula & 3 & & 1 & 1 & & & & & \\
\hline Humerus & & & & & & & 1 & & \\
\hline Radius & 2 & & 1 & & & & 1 & & \\
\hline Ulna & 3 & & 1 & & & & & & \\
\hline Metacarpus & & & 1 & & & & & & \\
\hline Pelvis & 1 & & 2 & & & & & & \\
\hline Femur & & & & 1 & 1 & & & & \\
\hline Tibia & & & & & & & 1 & & \\
\hline Talus & 8 & & & 2 & & & & 1 & 1 \\
\hline Metatarsus & & & 1 & & & & & & \\
\hline Phalanx 1 & 9 & & & & & & 1 & & \\
\hline Phalanx 2 & 4 & & & & & & & & \\
\hline Phalanx 3 & 1 & & & & & & & & 1 \\
\hline Metapodalia & & & 2 & & & & & & \\
\hline TOTAL & 72 & 1 & 20 & 9 & 1 & 1 & 8 & 1 & 3 \\
\hline
\end{tabular}


Anexa 2. Biometrie - măsurătorile sunt după von den Driesch (1976) și sunt exprimate în milimetri.

Bos taurus

\begin{tabular}{|l|c|c|c|c|c|c|c|c|}
\hline Astragal & Cx 1 & Cx 1 & Cx 1 & Cx 1 & Cx 1 & Cx 1 & Cx 1 & Cx 1 \\
\hline GLI & 64,2 & 64,4 & 73,4 & 62,3 & 61,2 & 57,5 & 58,1 & 50,6 \\
\hline GLm & 58,8 & 59,6 & 68,4 & 58,9 & 56,4 & 52,1 & 52,3 & 47,8 \\
\hline DI & 35,4 & 35,7 & 40,3 & 35,7 & 33 & 32,1 & 31,3 & 27,7 \\
\hline Dm & 36,9 & 35,7 & 41,1 & 35,9 & 33,3 & 31,3 & 31 & 28,8 \\
\hline Bd & 42,9 & 42,9 & 47,3 & 39,8 & 39,3 & 35,7 & 36,6 & 30,8 \\
\hline
\end{tabular}

\begin{tabular}{|l|c|c|c|c|c|c|c|}
\hline Falanga 1 & Cx 1 & Cx 1 & Cx 1 & Cx 1 & Cx 1 & Cx 1 & Cx 1 \\
\hline GL & 56,8 & 59 & 50 & 50,3 & 56,2 & 50,7 & 56,8 \\
\hline BP & 30,5 & 33,3 & 30,8 & 30,5 & 31,8 & 29,4 & 27,9 \\
\hline SD & 25,5 & 29,7 & 26,3 & 24,5 & 28,4 & 23,3 & 20,8 \\
\hline Bd & 27,5 & 37,1 & 29,5 & 27,9 & 29,6 & 26,8 & 24,4 \\
\hline
\end{tabular}

\begin{tabular}{|l|c|c|c|c|}
\hline Falanga 2 & $C \times 1$ & $C \times 1$ & $C \times 1$ & $C \times 1$ \\
\hline GL & 32,7 & 37,7 & 36,3 & 40,6 \\
\hline BP & 25,4 & 30,3 & 27,2 & \\
\hline SD & 20,7 & 24,4 & 21,4 & 27,7 \\
\hline Bd & 21,5 & 26,9 & 22 & 31,3 \\
\hline
\end{tabular}

\section{Ovis aries}

\begin{tabular}{|l|c|}
\hline Astragal & $C \times 3$ \\
\hline GLI & 29,8 \\
\hline GLm & 27,3 \\
\hline DI & 16,3 \\
\hline Dm & 17,1 \\
\hline Bd & 19,4 \\
\hline Talie (ind. Teichert) & 675,70 \\
\hline
\end{tabular}

\section{Sus domesticus}

\begin{tabular}{|l|c|}
\hline Astragal & Cx 1 \\
\hline GLI & 42,7 \\
\hline GLm & 39,1 \\
\hline DI & 20,7 \\
\hline Dm & 23,6 \\
\hline Bd & 23,5 \\
\hline Talie (ind. Teichert) & 787,3 \\
\hline
\end{tabular}


Anexa 3.

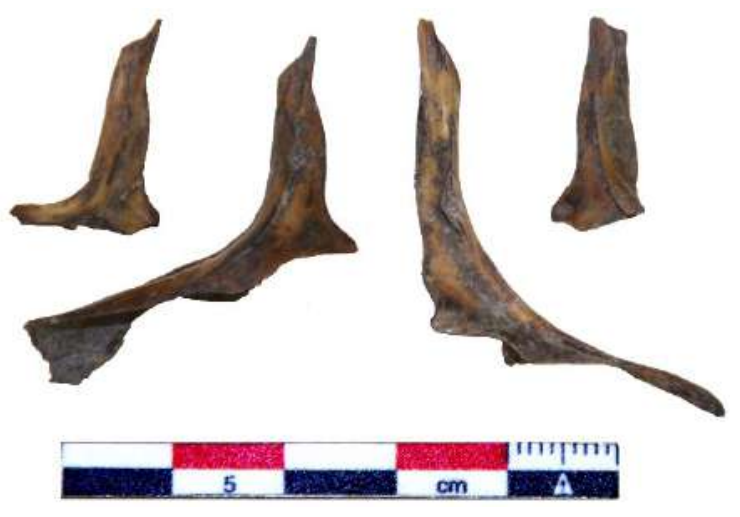

Cleithrum de plătică (Abramis brama).

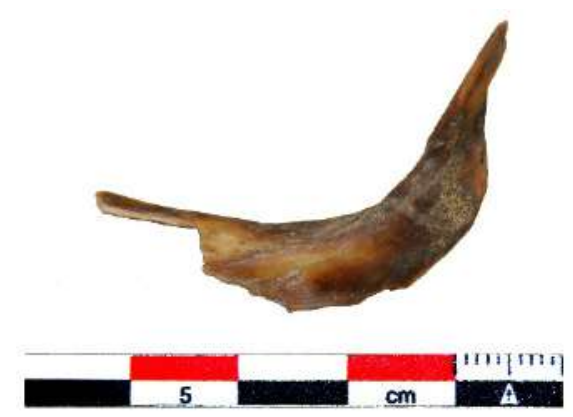

3. Cleithrum de ştiucă (Esox lucius).

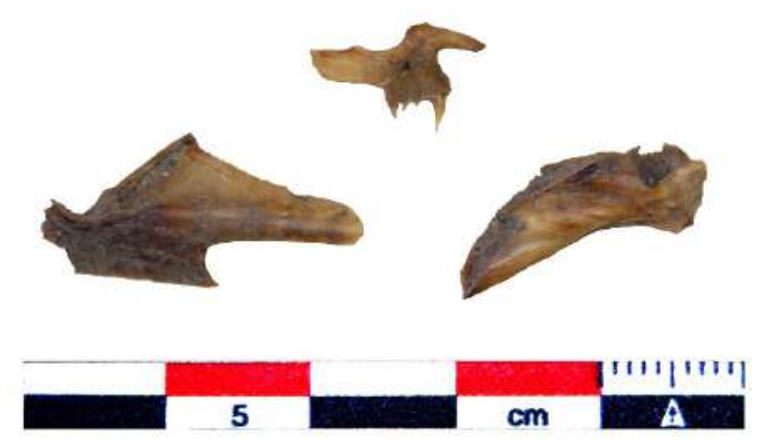

5. Palatin (sus), articular și dentar de șalău (Sander lucioperca).

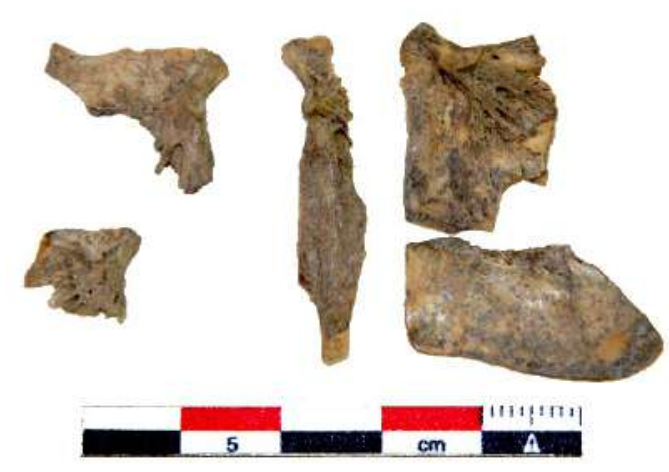

2. Operculare de crap (Ciprinus carpio).

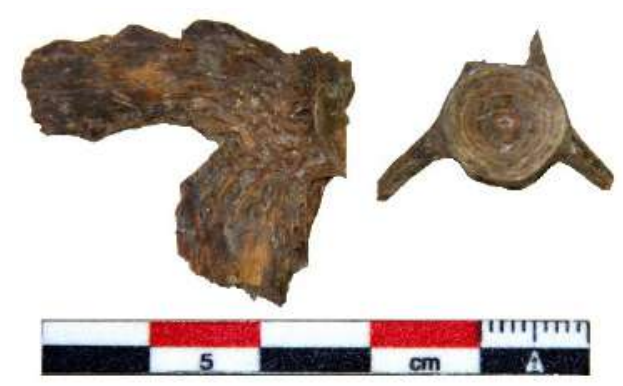

4. Opercular și vertebră de somn (Silurus glanis).

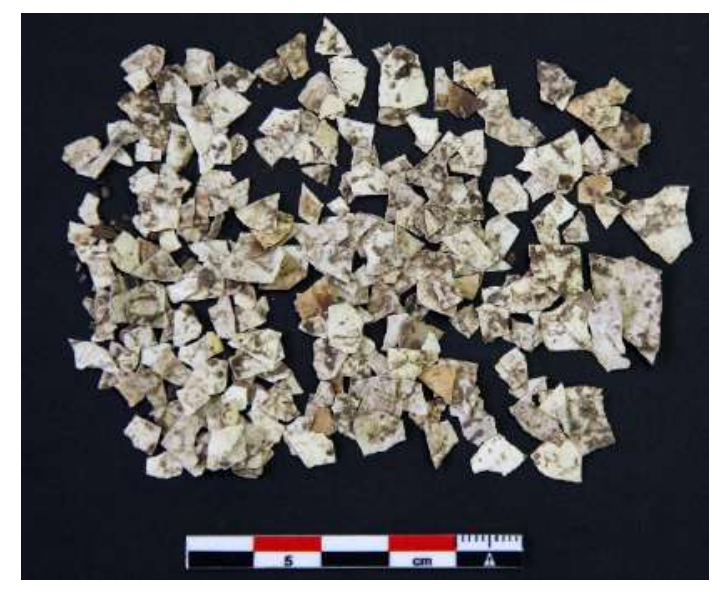

6. Fragmente coji ouă de păsări. 

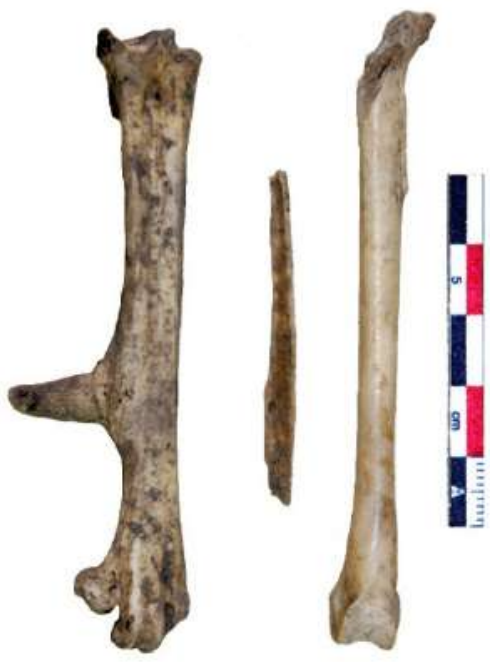

7. Tarso-metatars și tibio-tarsuri de găină (Gallus domesticus).

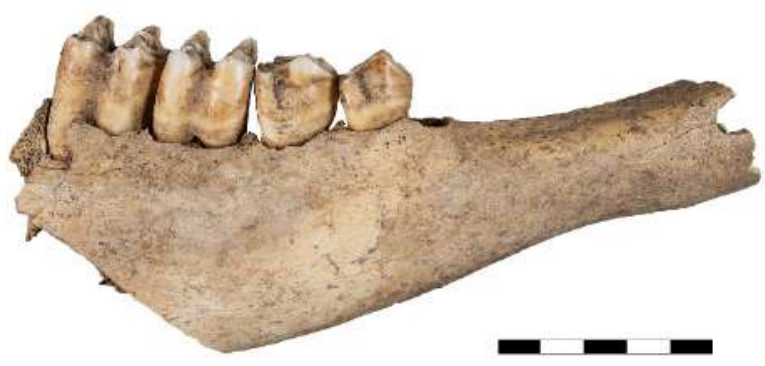

9. Mandibulă de vită (Bos taurus).
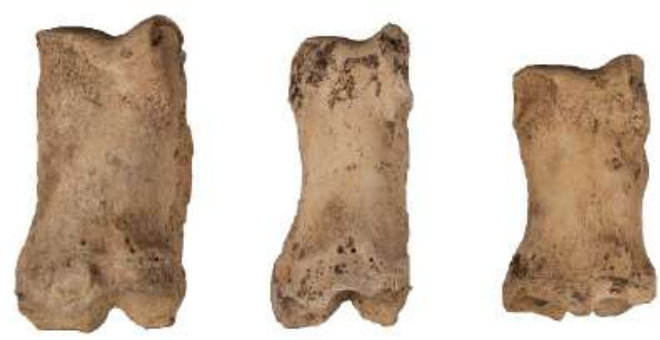

11. Falange 1 de vită (Bos taurus).
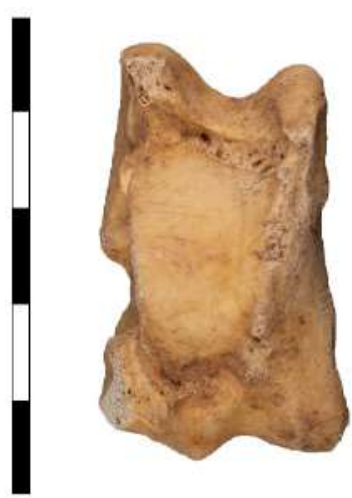

13. Astragal de porc (Sus domesticus).

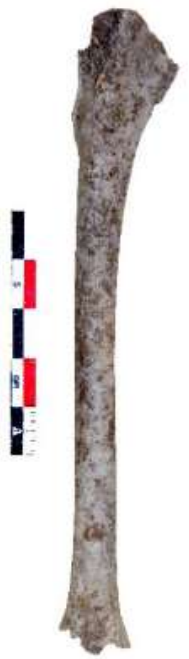

8. Humerus de gâscă (Anser sp.).

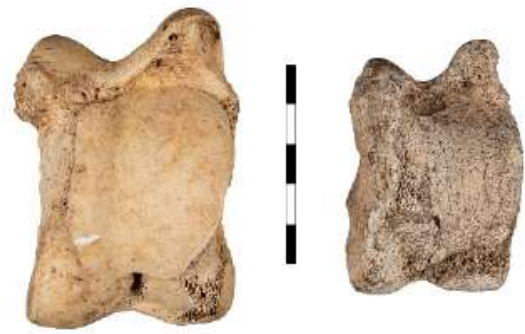

10. Astragale de vită (Bos taurus).

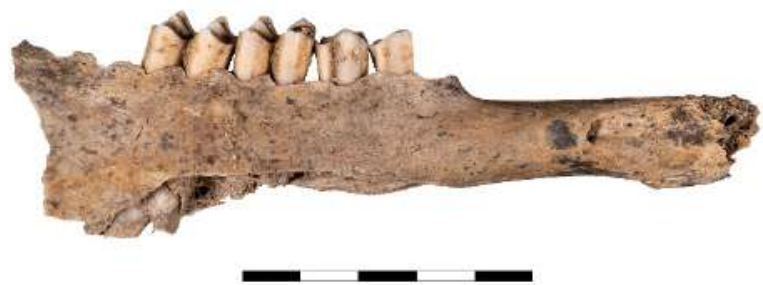

12. Mandibulă de oaie (Ovis aries).

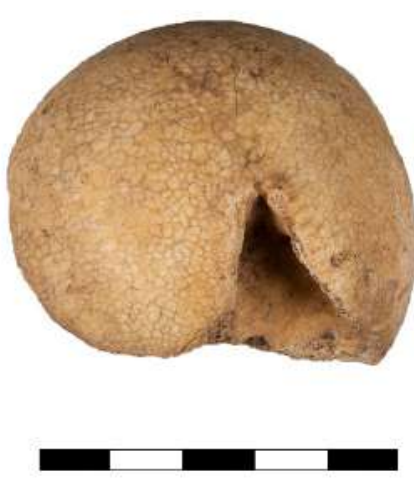

14. Cap femural de cal (Equus caballus). 


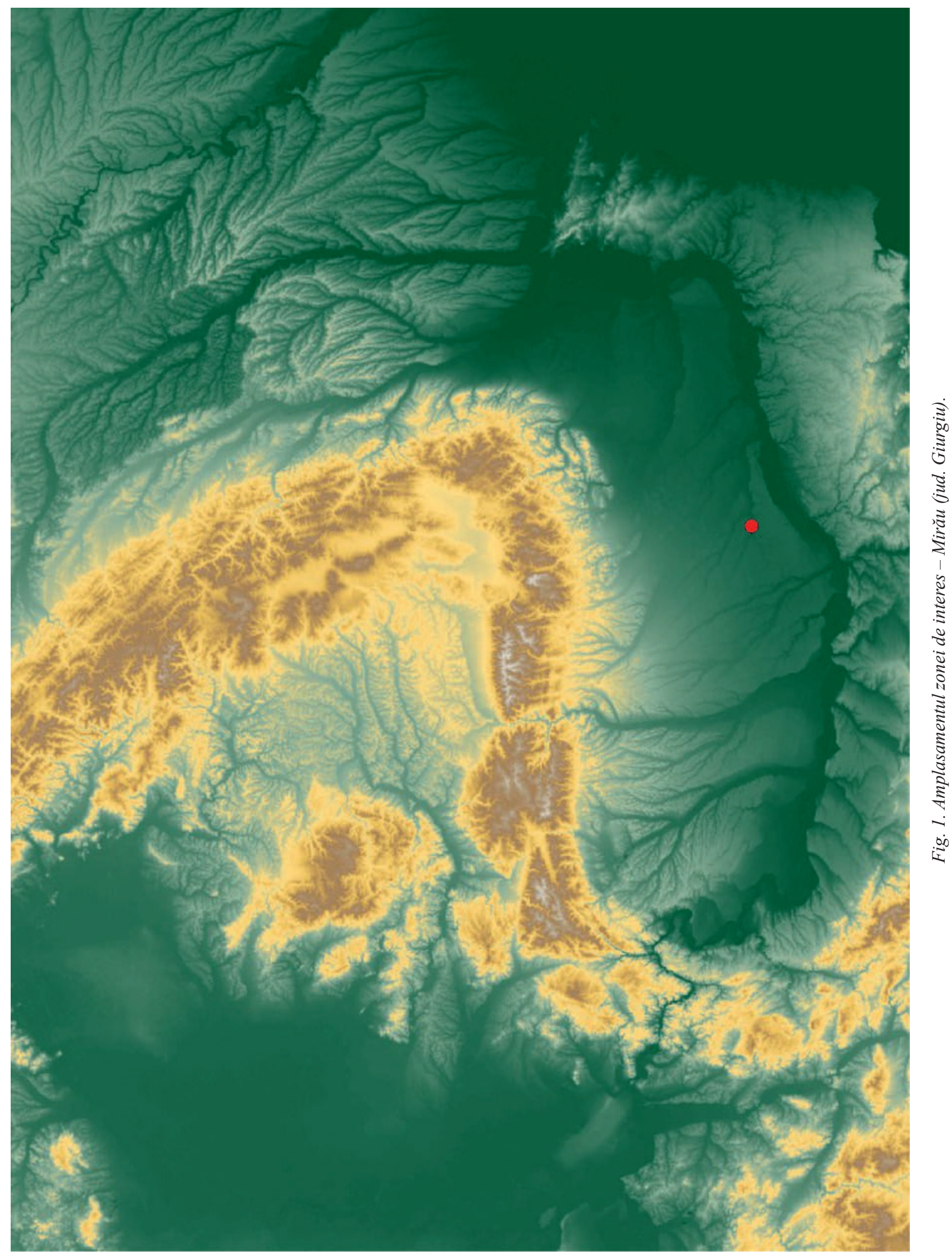




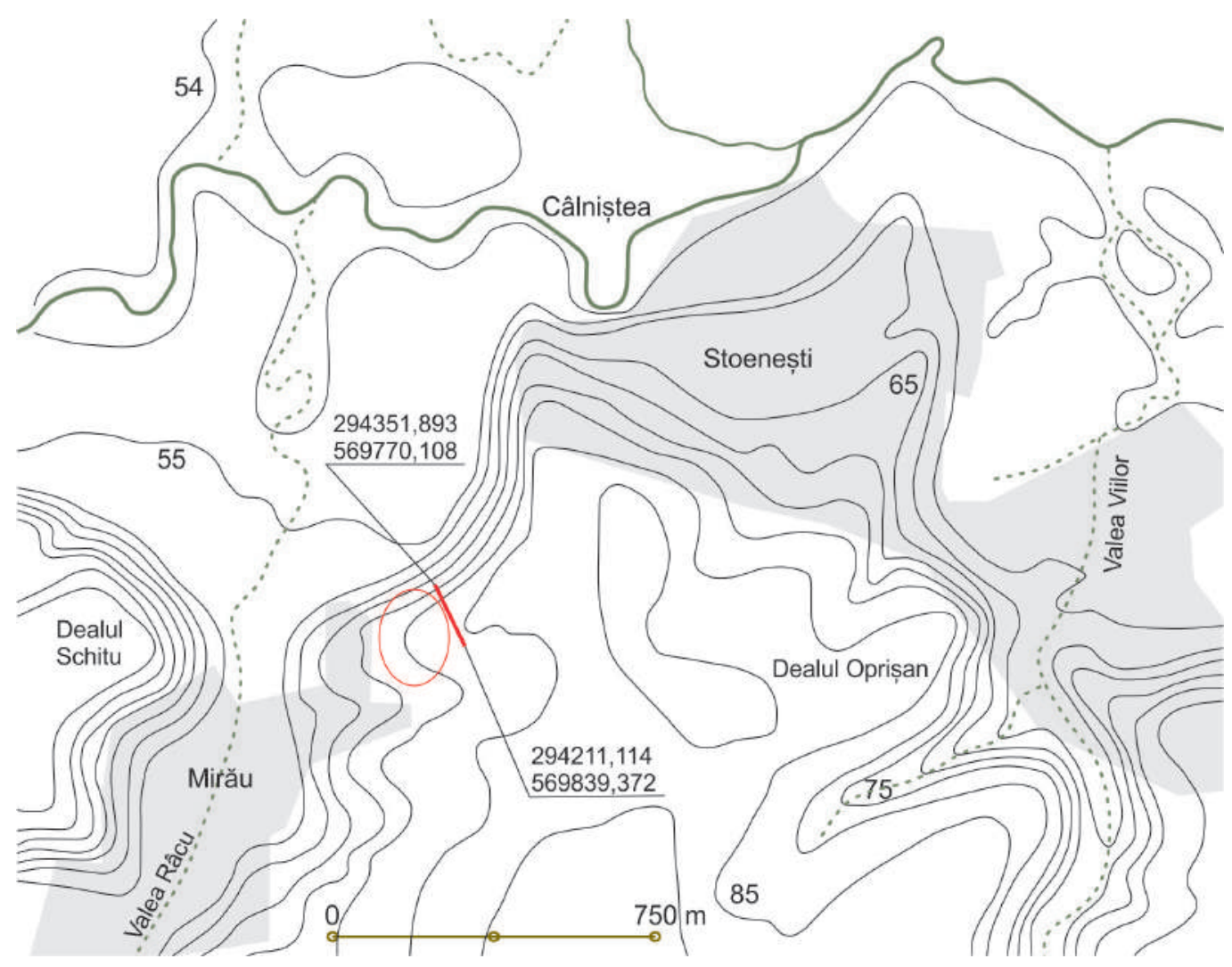

Fig. 2. Amplasamentul stațiunii de la Mirău prin secțiunea magistrală de cercetare din martie 2020 (marcată prin două puncte extreme având coordonate ST 70). Ovalul roșu indică zona grajdurilor demolate in anii ' 80 ai secolului trecut.

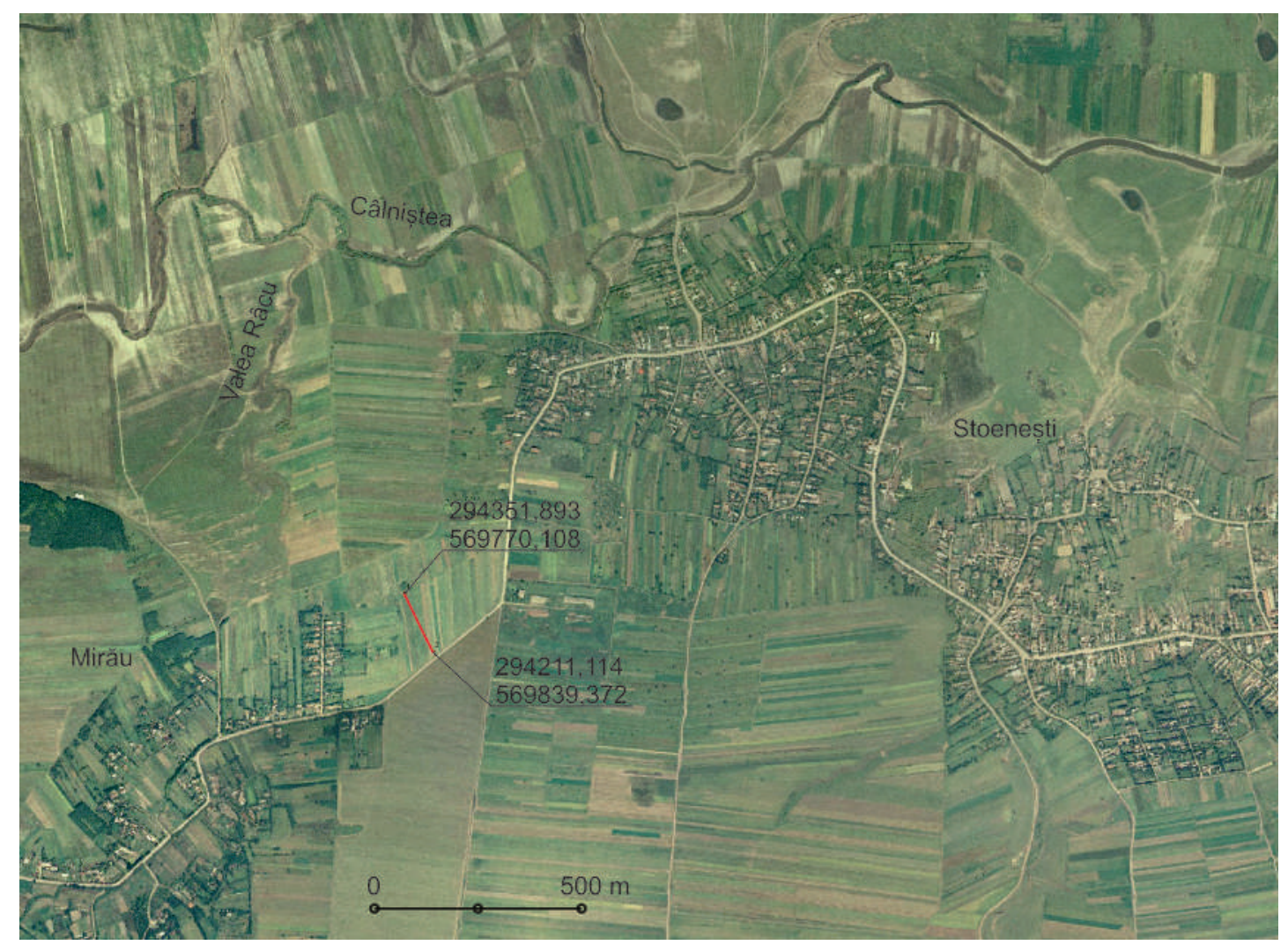

Fig. 3. Amplasamentul stațiunii de la Mirău pe ortofotoplan. 

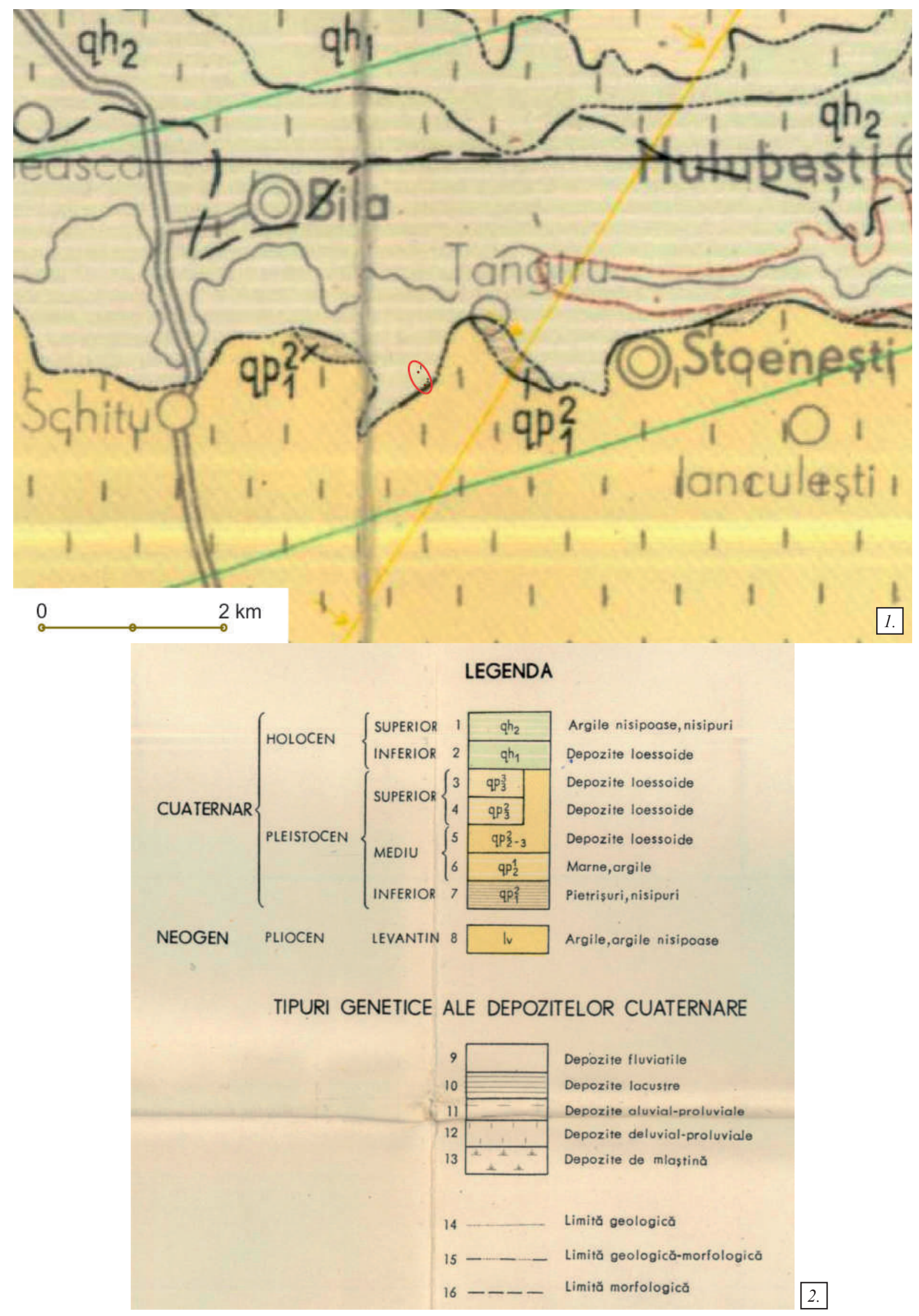

Fig. 4. Harta geologică (1) a zonei stațiunii de la Mirău; 2. legenda hărții geologice (http://www.geo-spatial.org/ download/harta-geologica-a-romaniei-scara-1-200-000). 


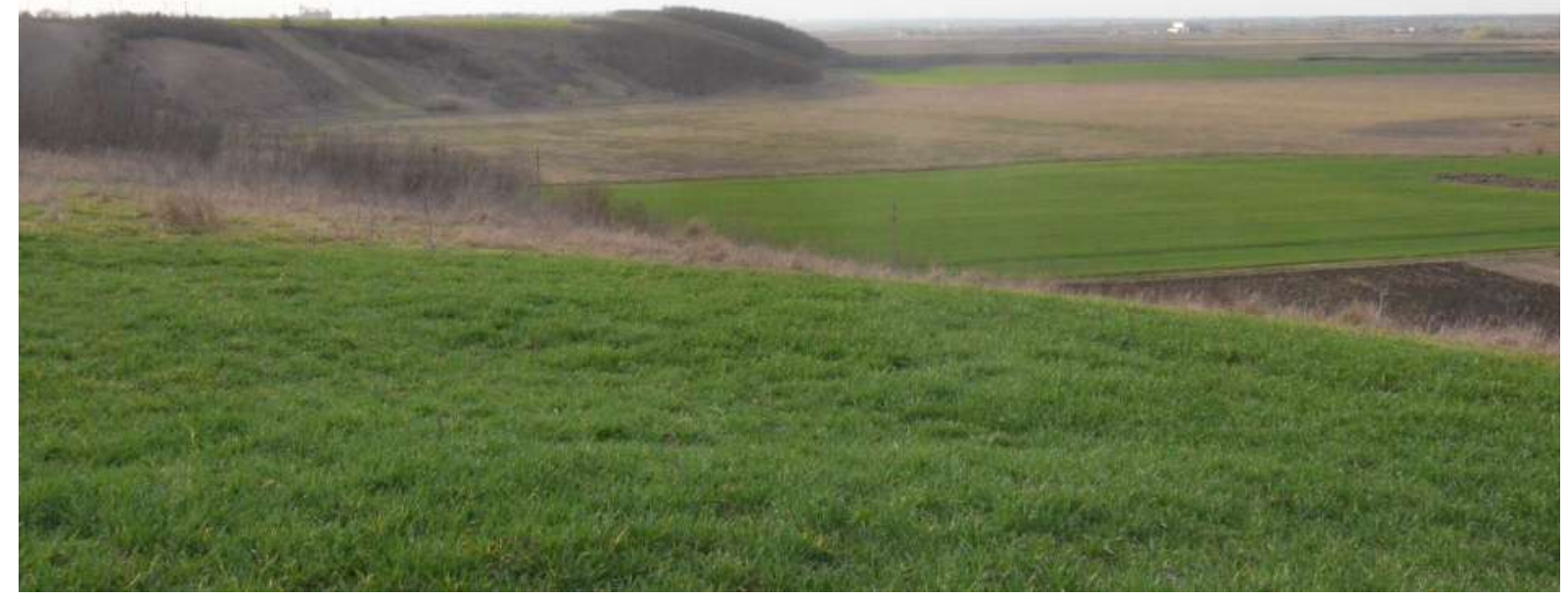

Fig. 5. Stațiunea de la Mirău. Vedere de pe sit asupra zonei de confluență a Câlniștei cu Valea Râcu (foto Adrian Vladu).

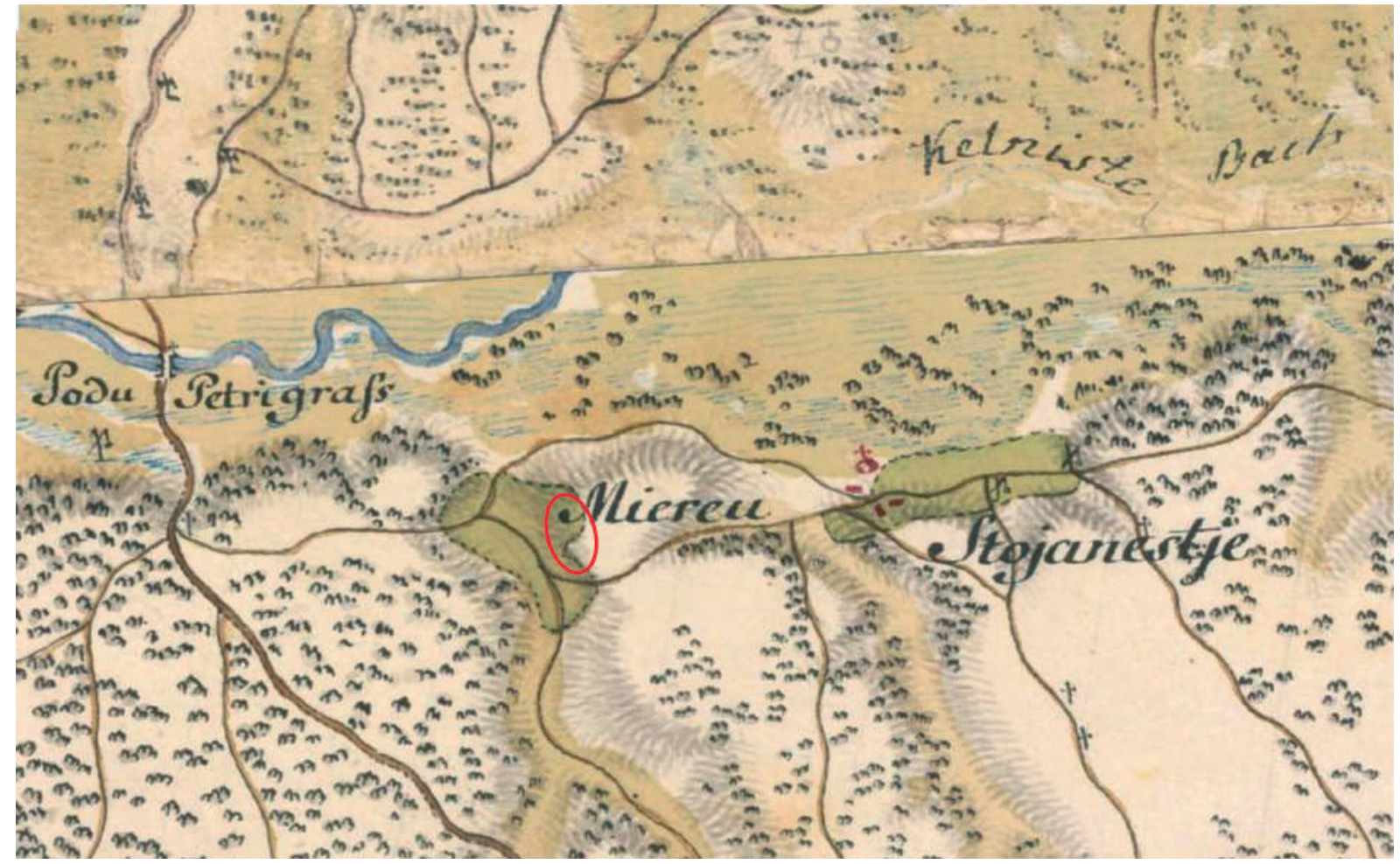

Fig. 6. Stațiunea de la Mirău. Prima ridicare topografică austriacă (Specht). 


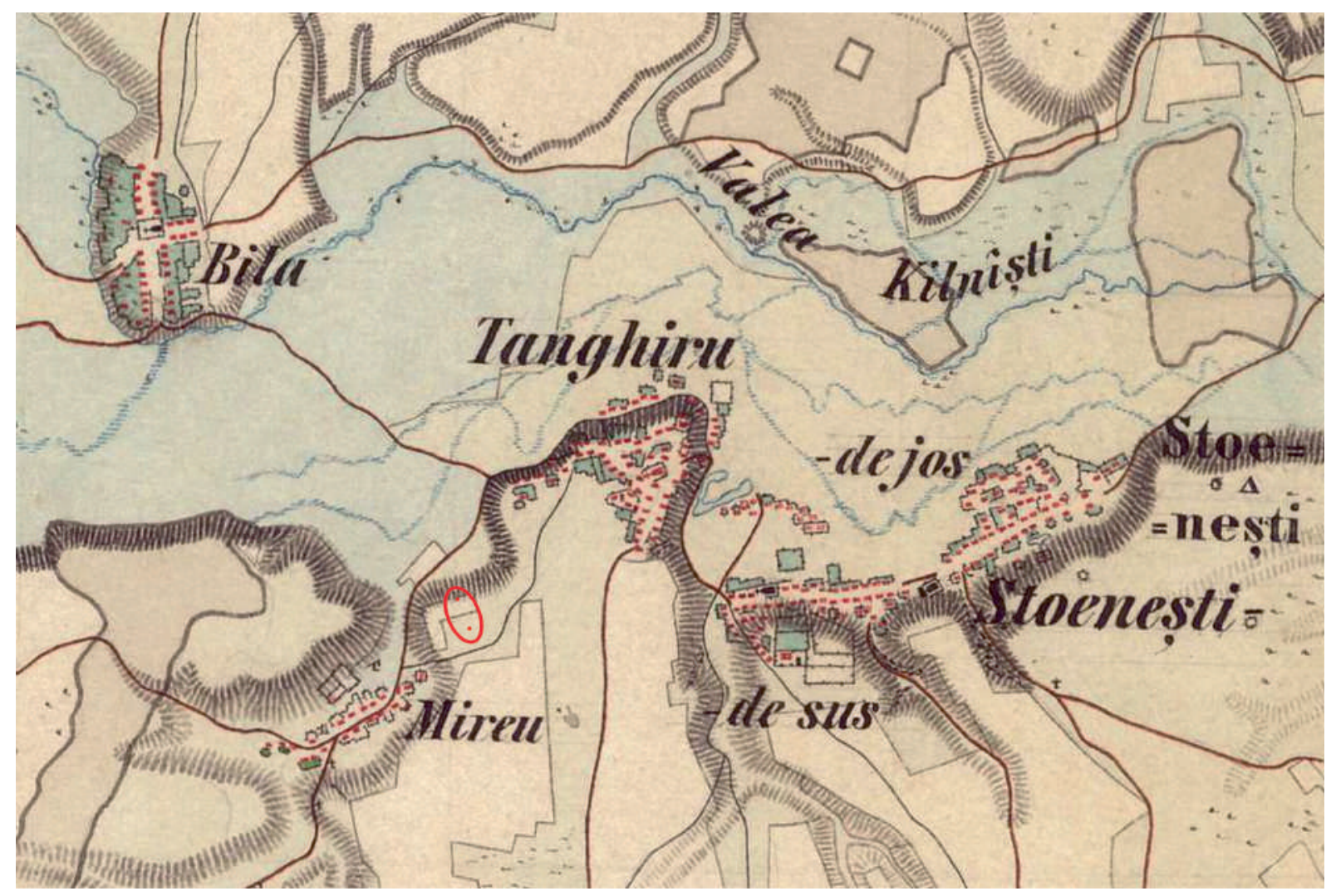

Fig. 7. Stațiunea de la Mirău A doua ridicare topografică austriacă.

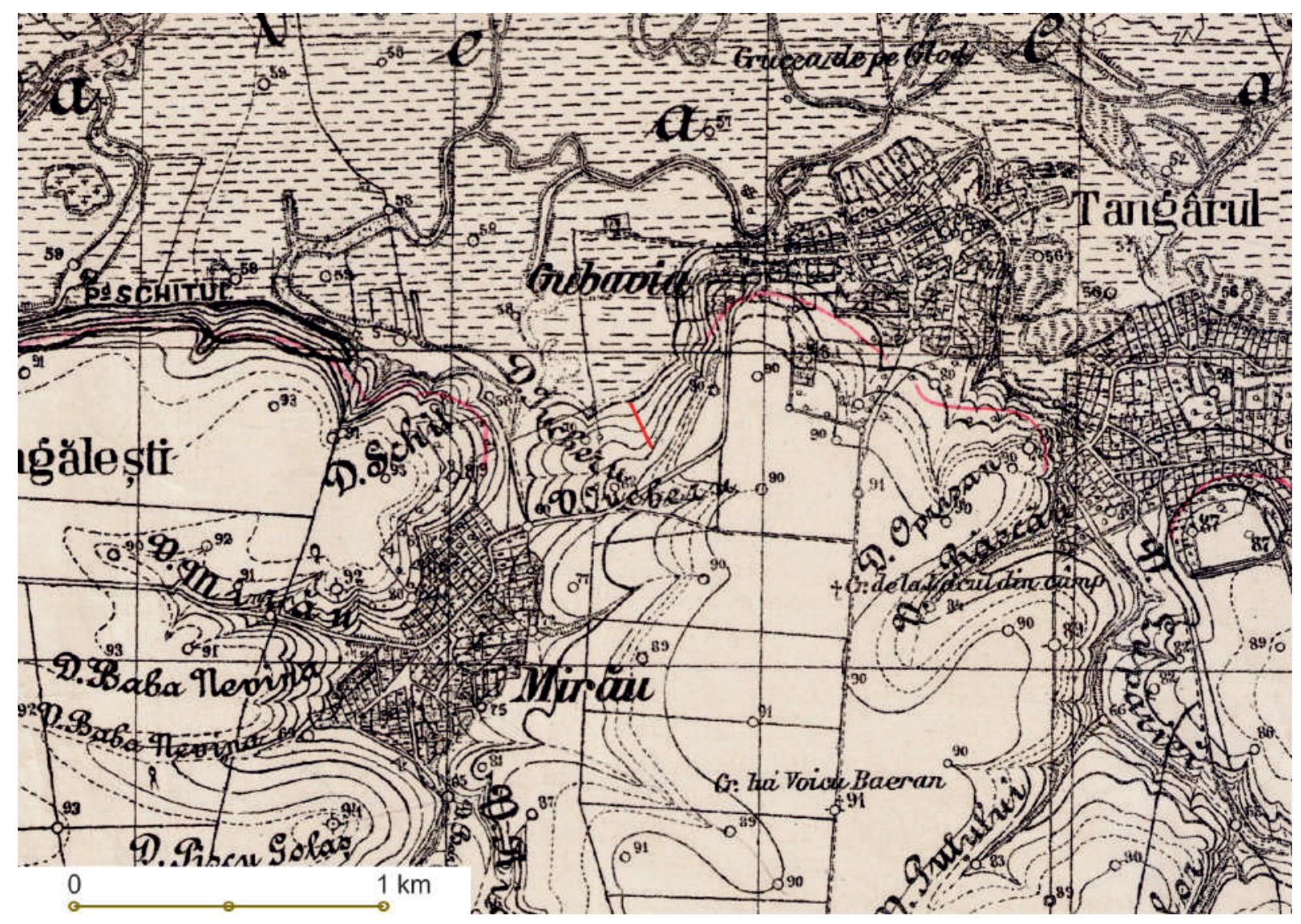

Fig. 8. Stațiunea de la Mirău. Planul Director de Tragere (foaia 4140, Pângălești). 


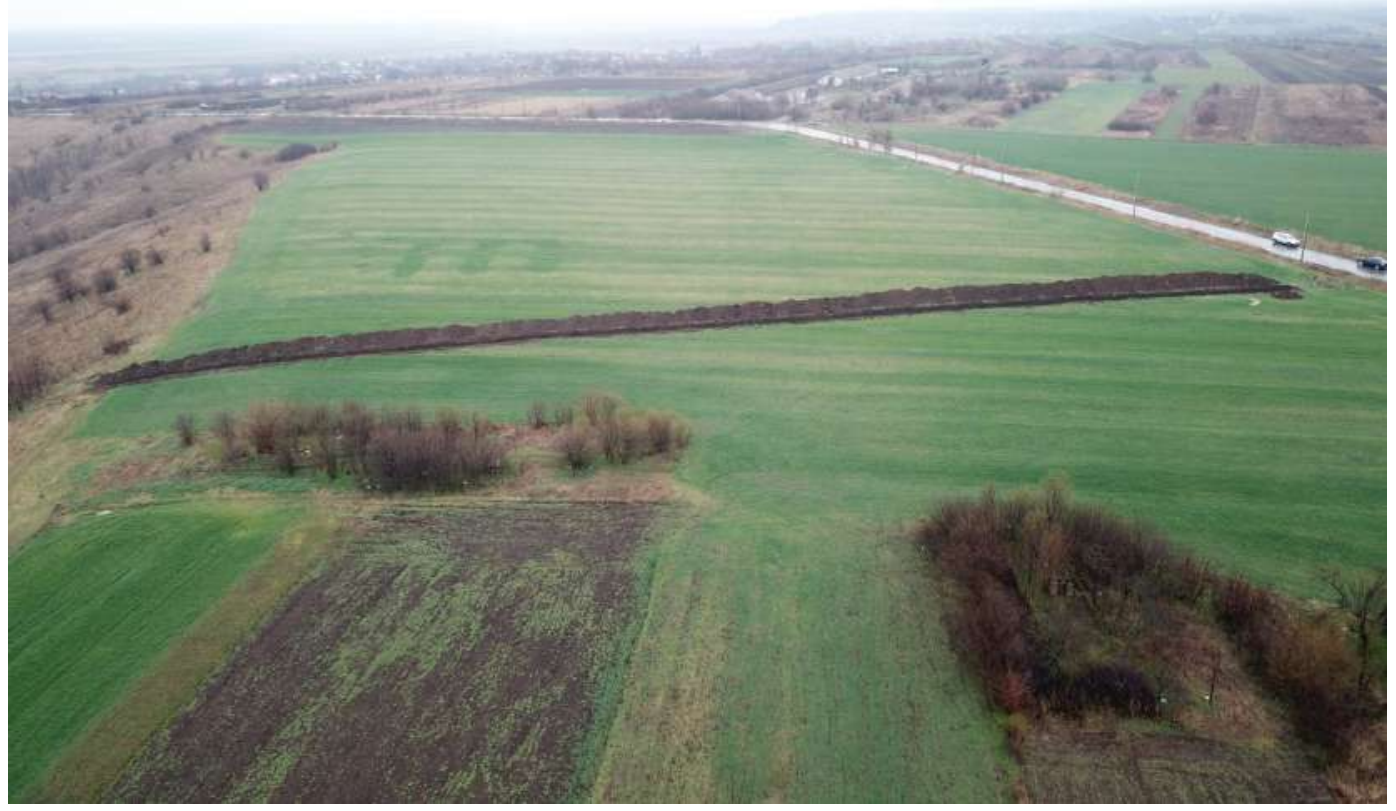

Fig. 9. Stațiunea de la Mirău. Vedere aeriană dinspre vest (în prim plan-ruinele a două grajduri din perioada comunistă) (foto Cătălin Borangic).

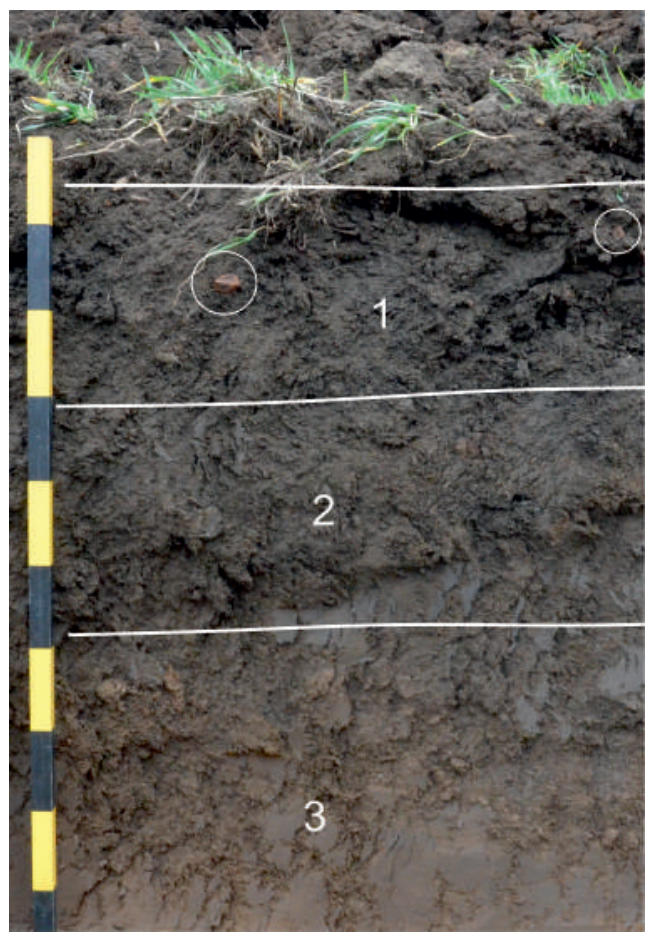

Fig. 10. Stațiunea de la Mirău. Detaliu stratigrafic (indicativele își regăsesc descrierea în text; limitele marcate nu reprezintă un desen după o fotografie, ci sunt menite la a evidenția suplimentar situația stratigrafică) - se observă cu ușurință prezența materialelor contemporane (evidențiate prin contururi ovale albe). 


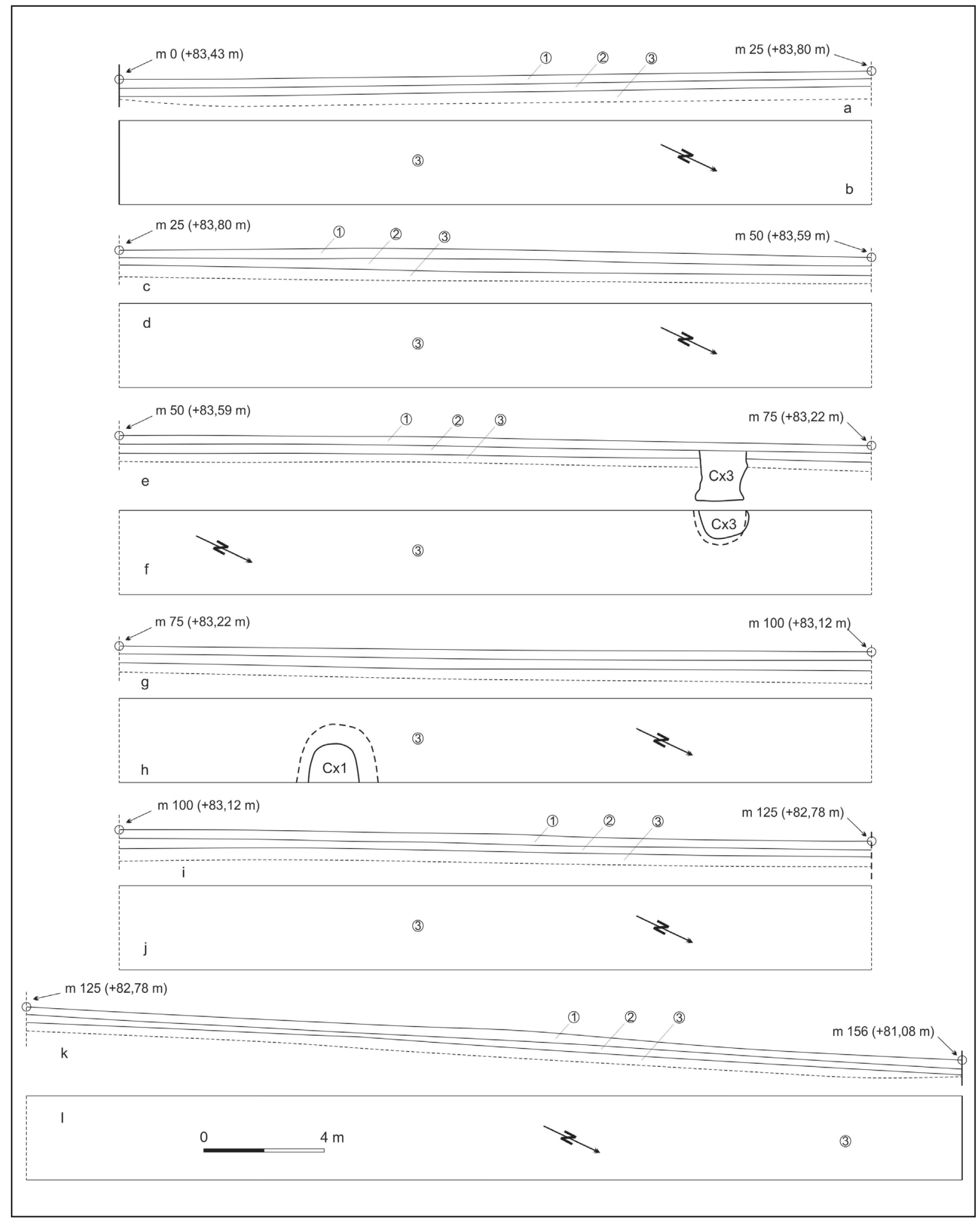

Fig. 11. Profilul magistral vestic și planul secțiunii cercetate (indicativele își regăsesc descrierea în text). 


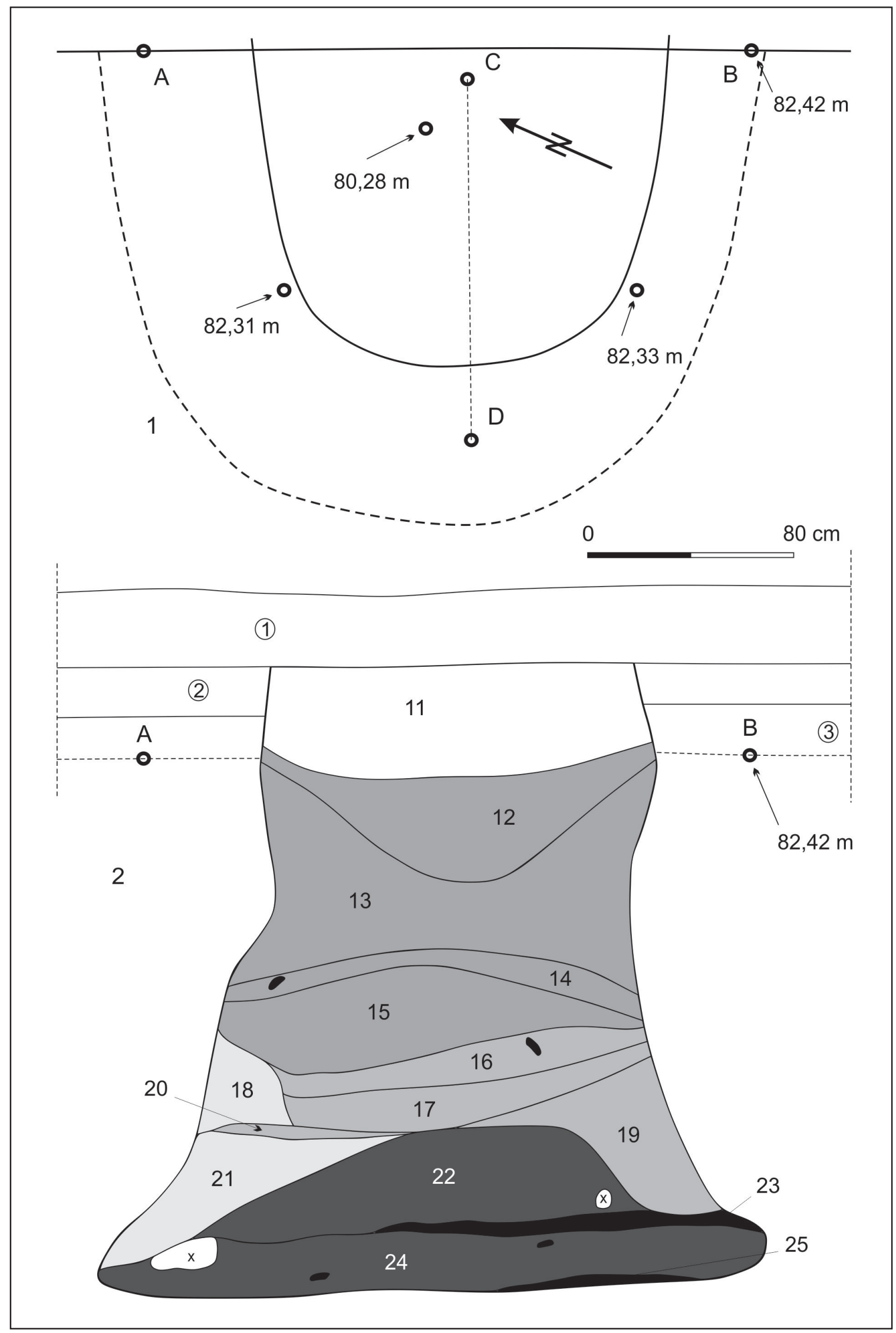

Fig. 12. Stațiunea de la Mirău. Cx1. Plan (1) și profil (2) (indicativele își regăsesc descrierea în text). Scara de desen 1:20. Legendă: $\mathrm{X}$-fragment osos,

fragment ceramic). 


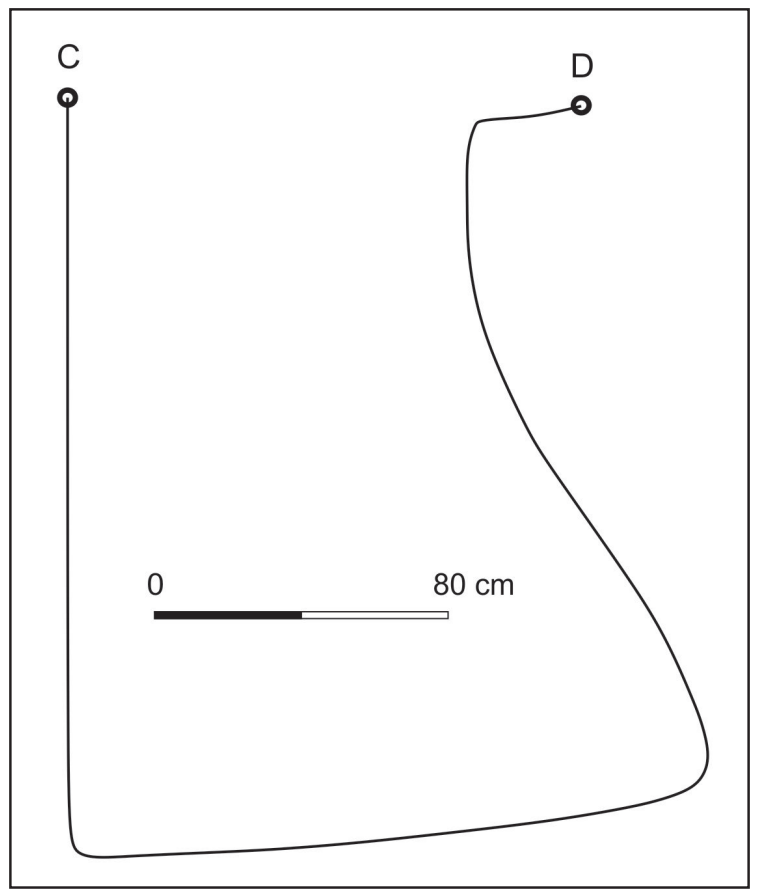

Fig. 13. Stațiunea de la Mirău. Profil negativ (CD) al Cxl.

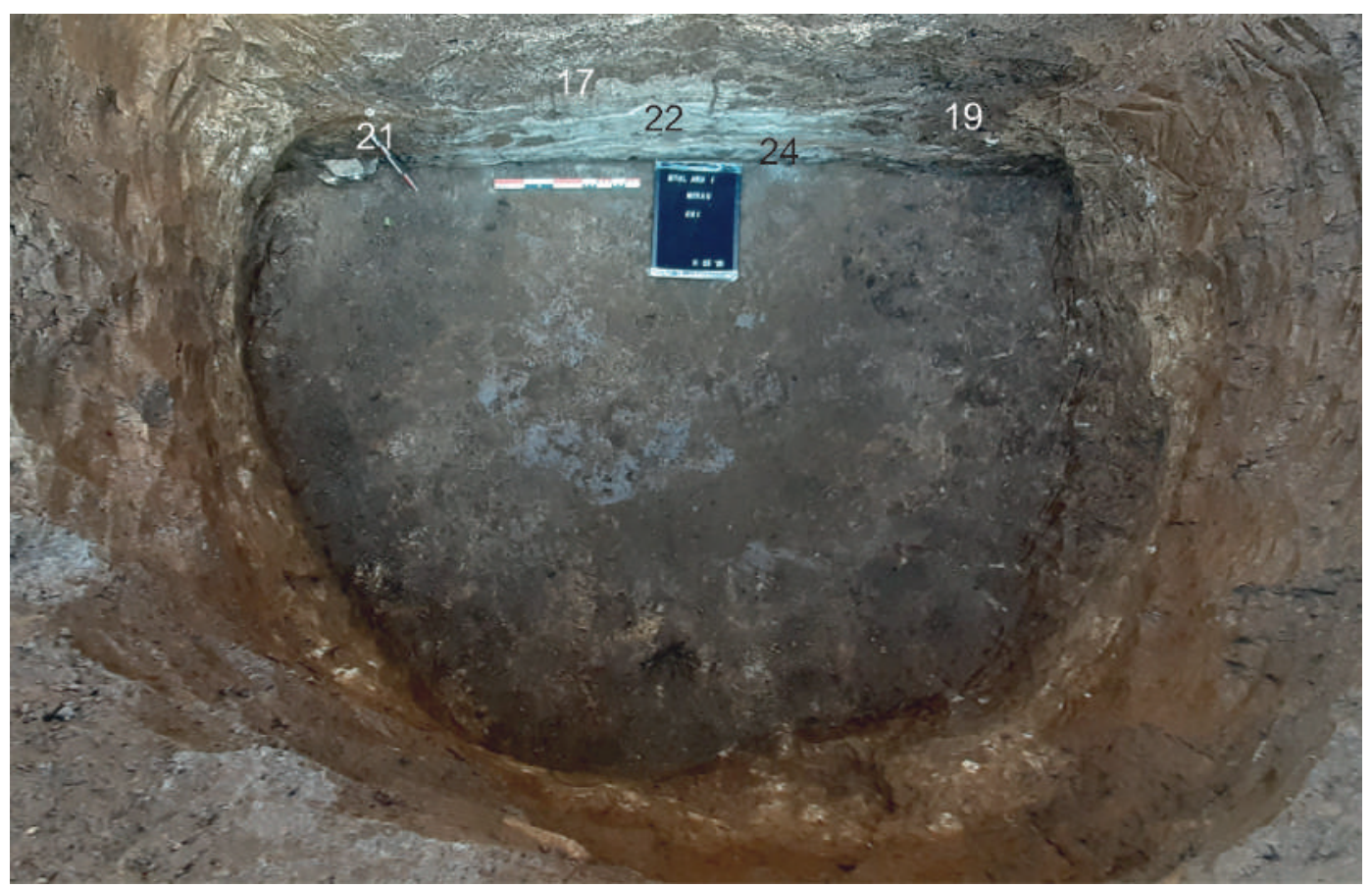

Fig. 14. Stațiunea de la Mirău. Cxl - vedere de sus (după încheierea cercetării) (foto Cătălin Bem).

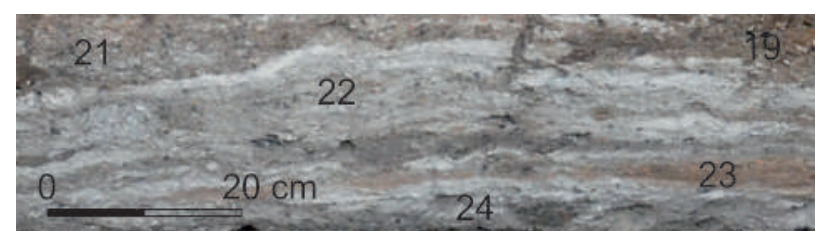

Fig. 15. Stațiunea de la Mirău. Cxl - detaliu al profilului magistral din zona primelor unități stratigrafice acumulate în groapă (indicativele își regăsesc descrierea în text) (foto Cătălin Bem). 


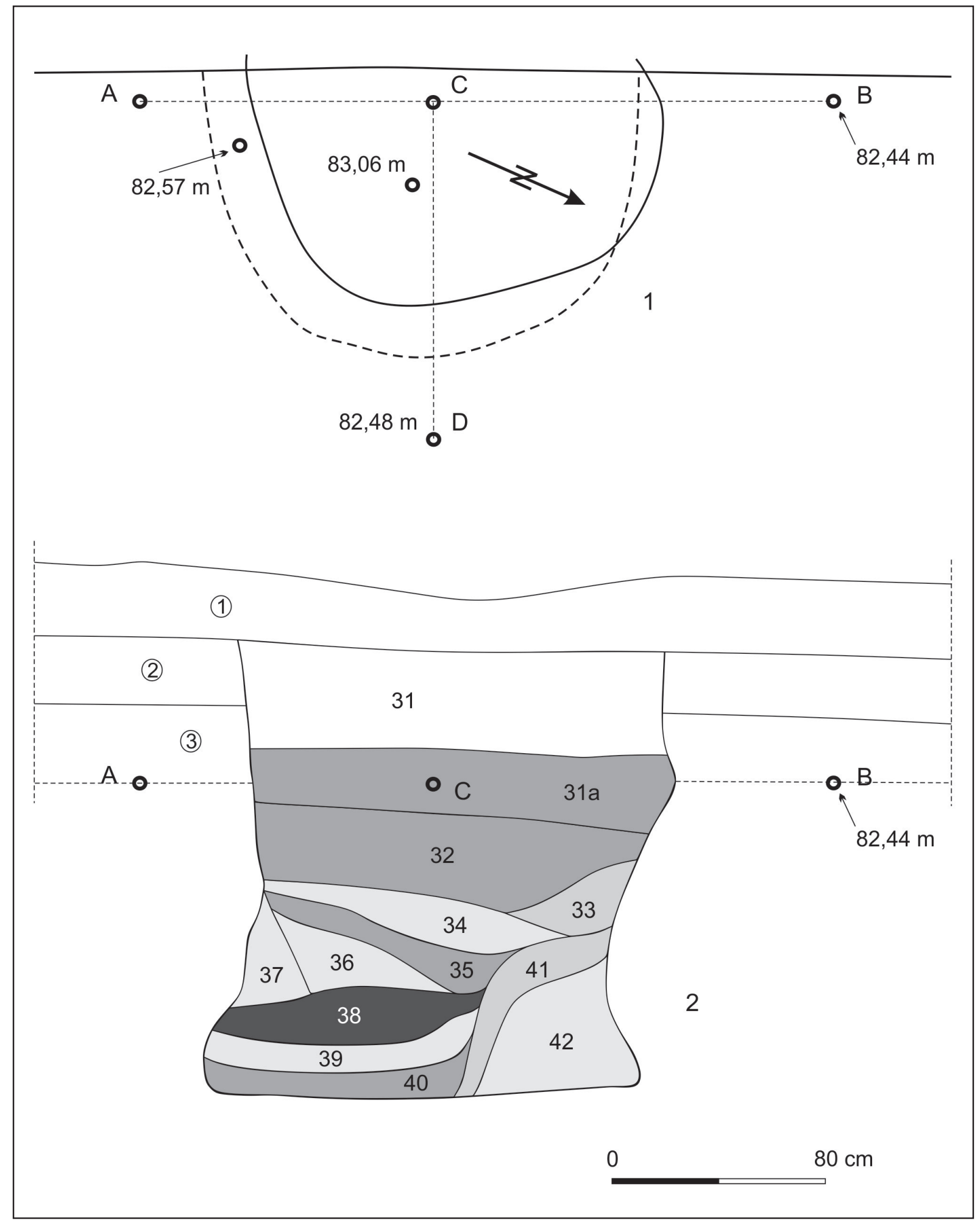

Fig. 16. Stațiunea de la Mirău. Cx3. Plan (1) și profil (2) (indicativele își regăsesc descrierea în text). Scara de desen 1:20. 


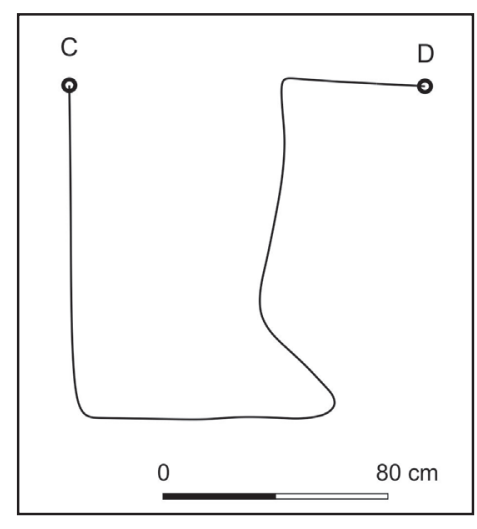

Fig. 17.

Stațiunea de

la Mirău.

Profil negativ

(CD) al Cx3.

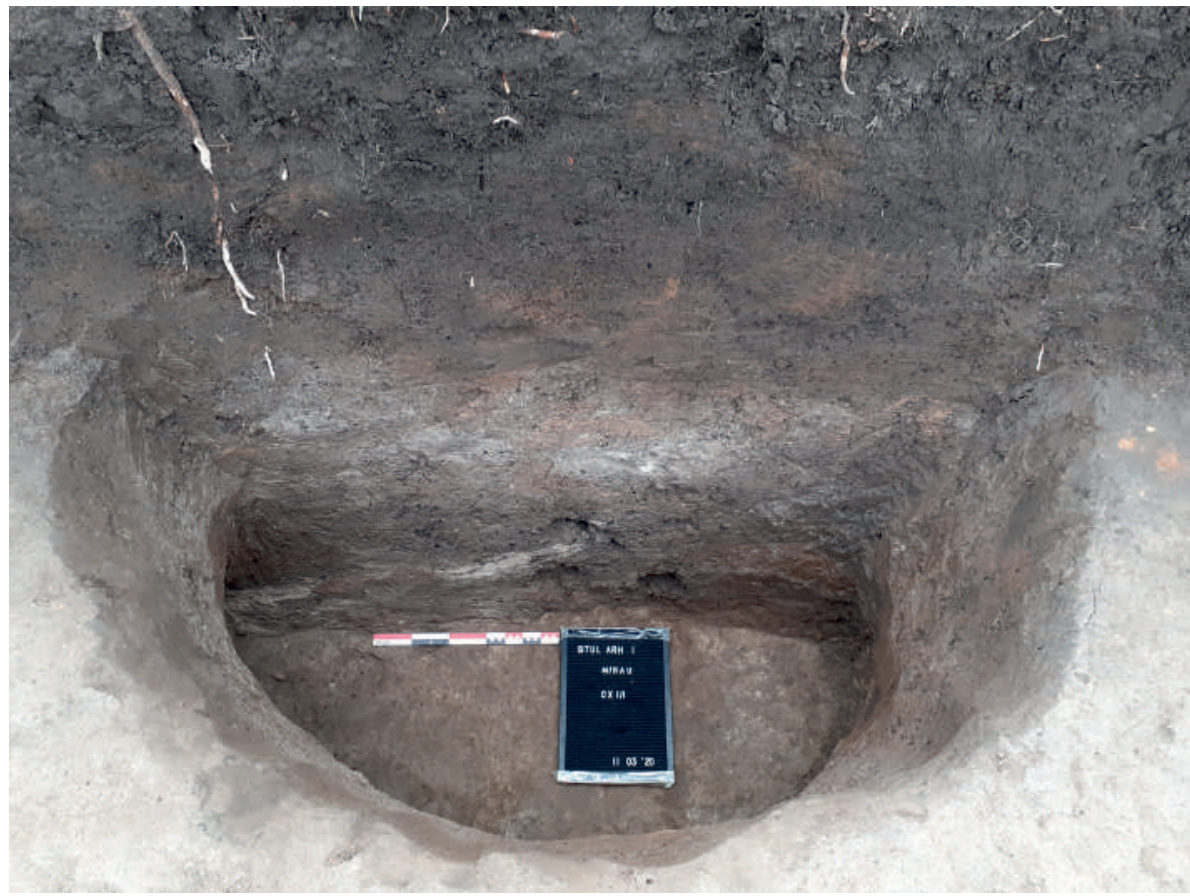

Fig. 18. Stațiunea de la Mirău. Cx3 - vedere de sus (după încheierea cercetării) (foto Adrian Vladu).

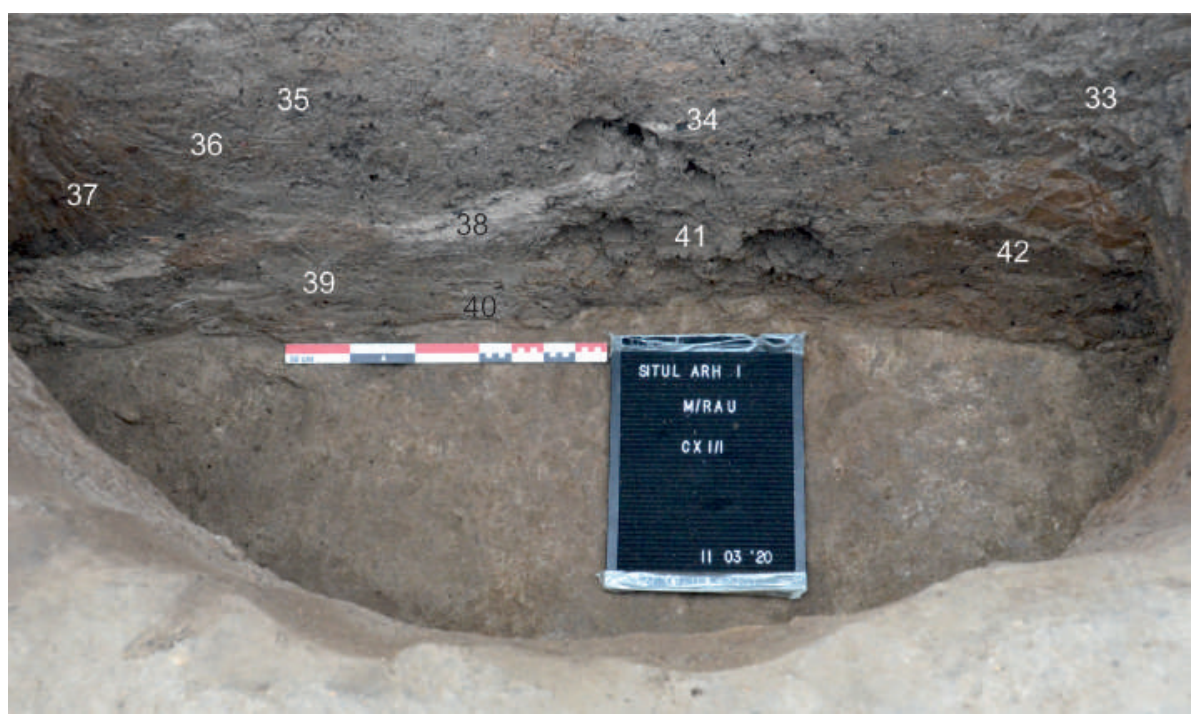

Fig. 19. Stațiunea de la Mirău. Cx3 - detaliu al profilului (foto Adrian Vladu). 

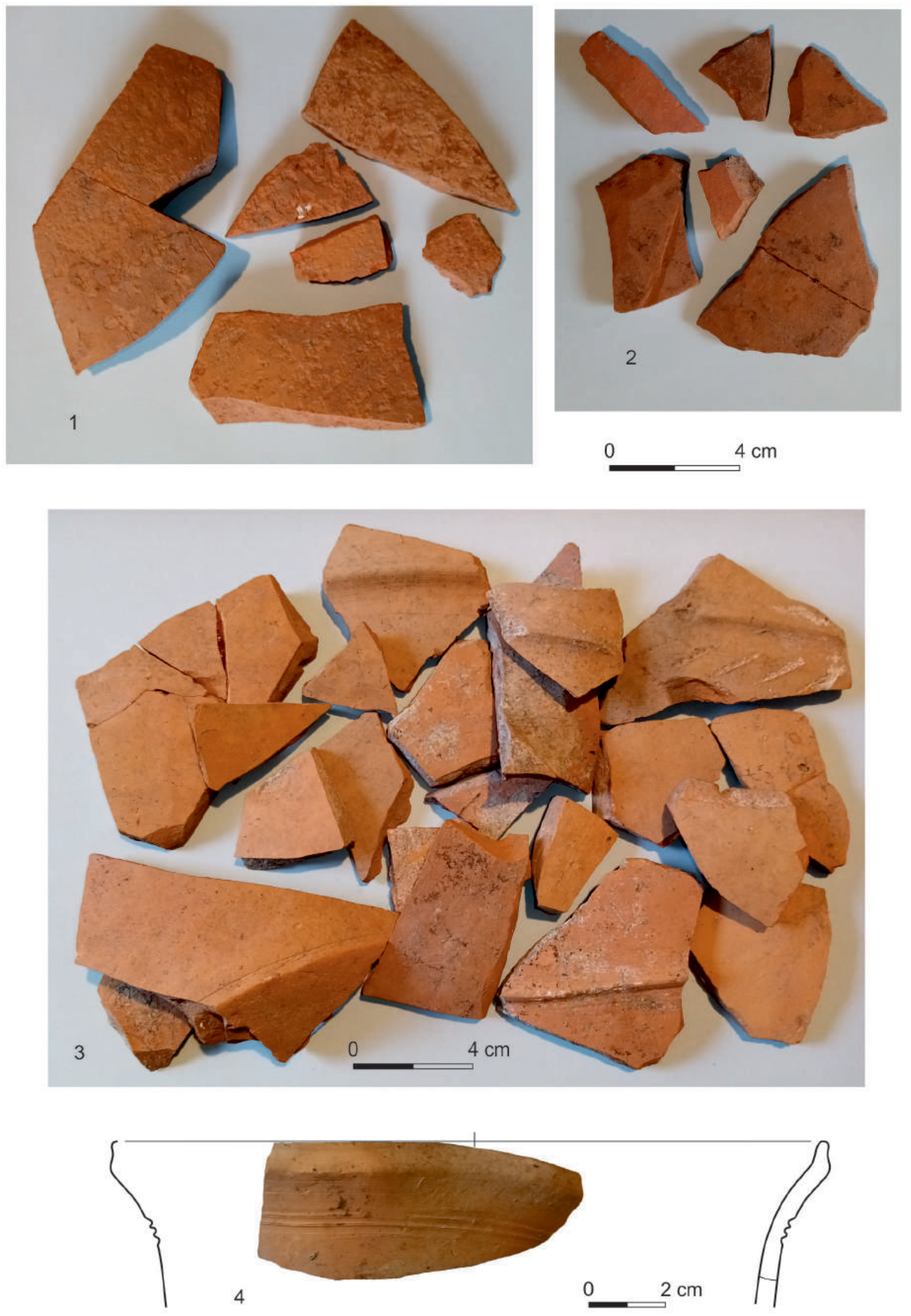

Fig. 20. Stațiunea de la Mirău. Ceramică, tipul de pastă 1 (P1). 1-2. Cx1, US16; 3. Cx1 (primul moment de umplere), vas 8; 4. Cx1 (primul moment de umplere), vas 7. 

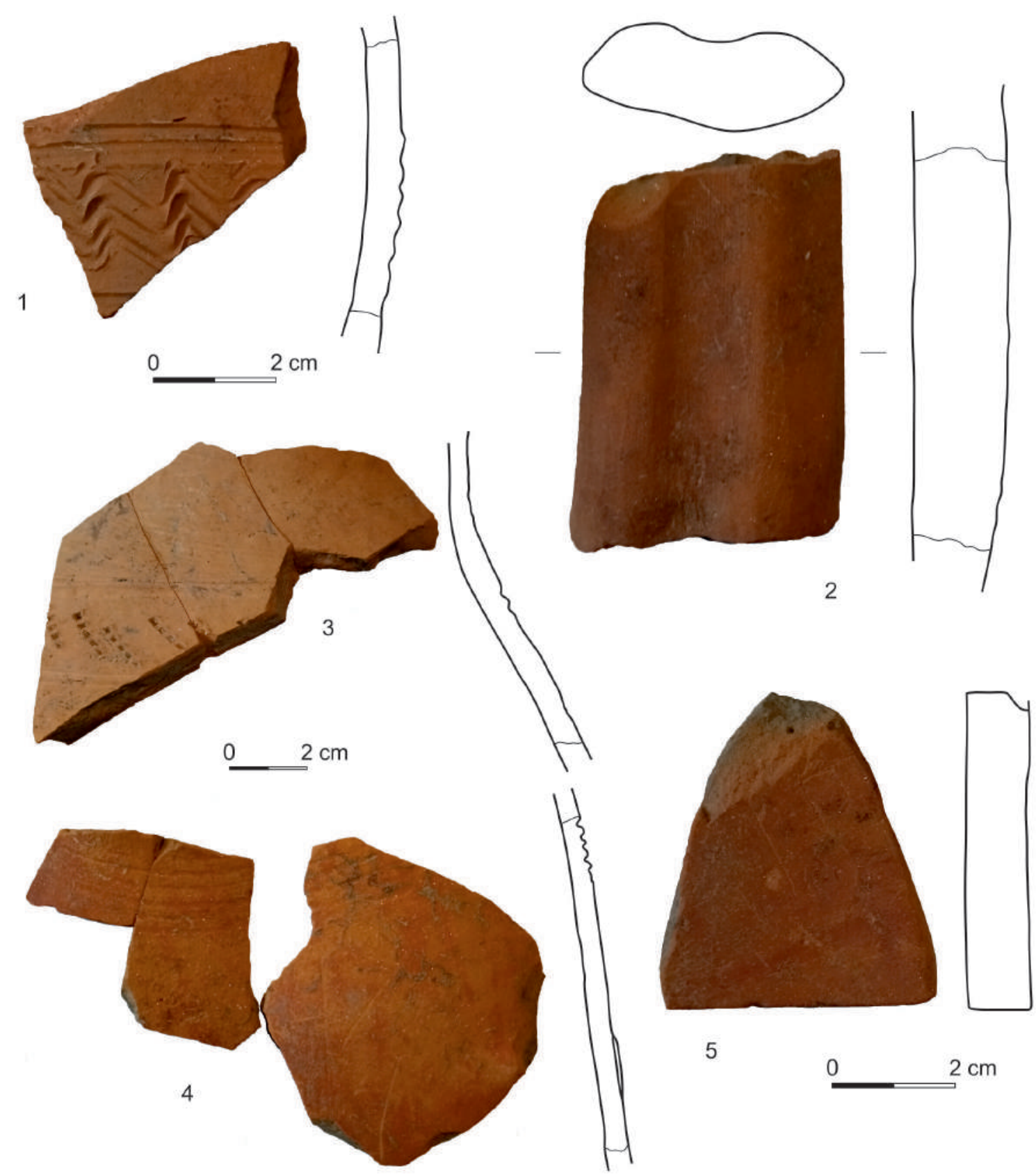

5
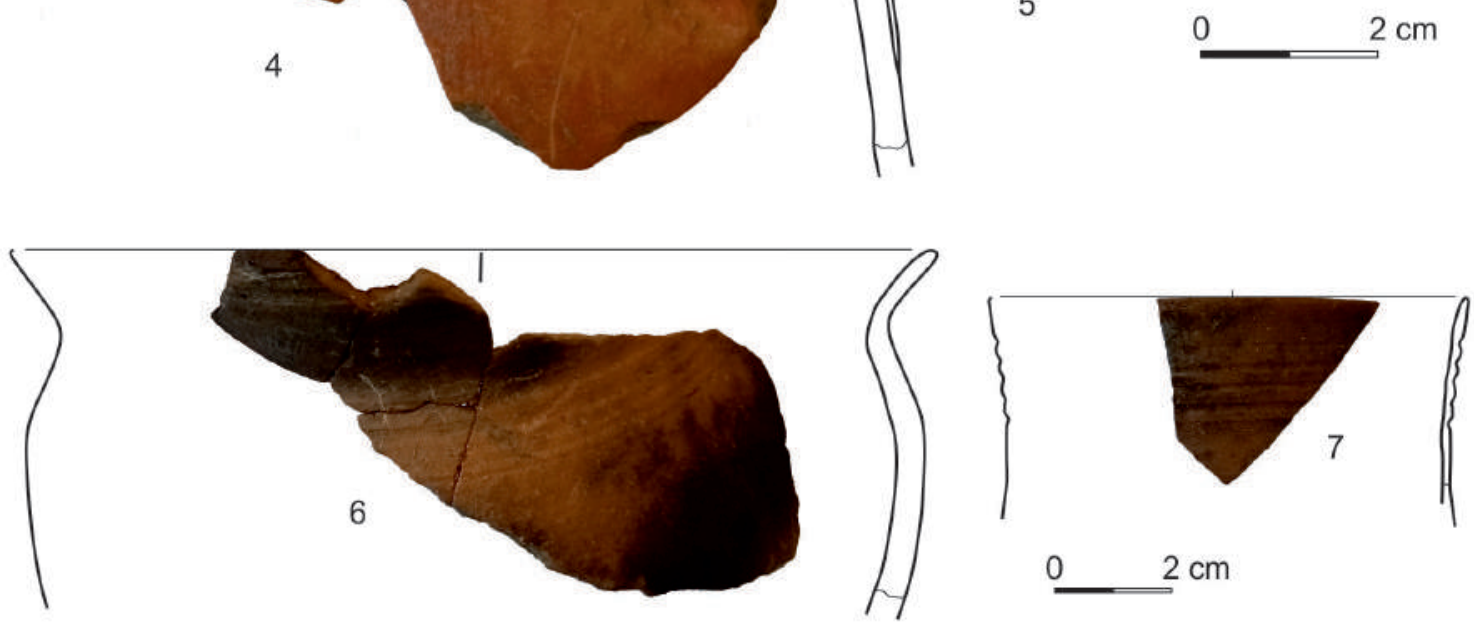

Fig. 21. Stațiunea de la Mirău. Cxl (US16). Fragmente ceramice (1-4, 6-7) și jeton (5). 1-3. Pastă tip 1 (P1); 4-5. Pastă tip 11 (P11); 6-7. Pastă tip 2 (P2). 

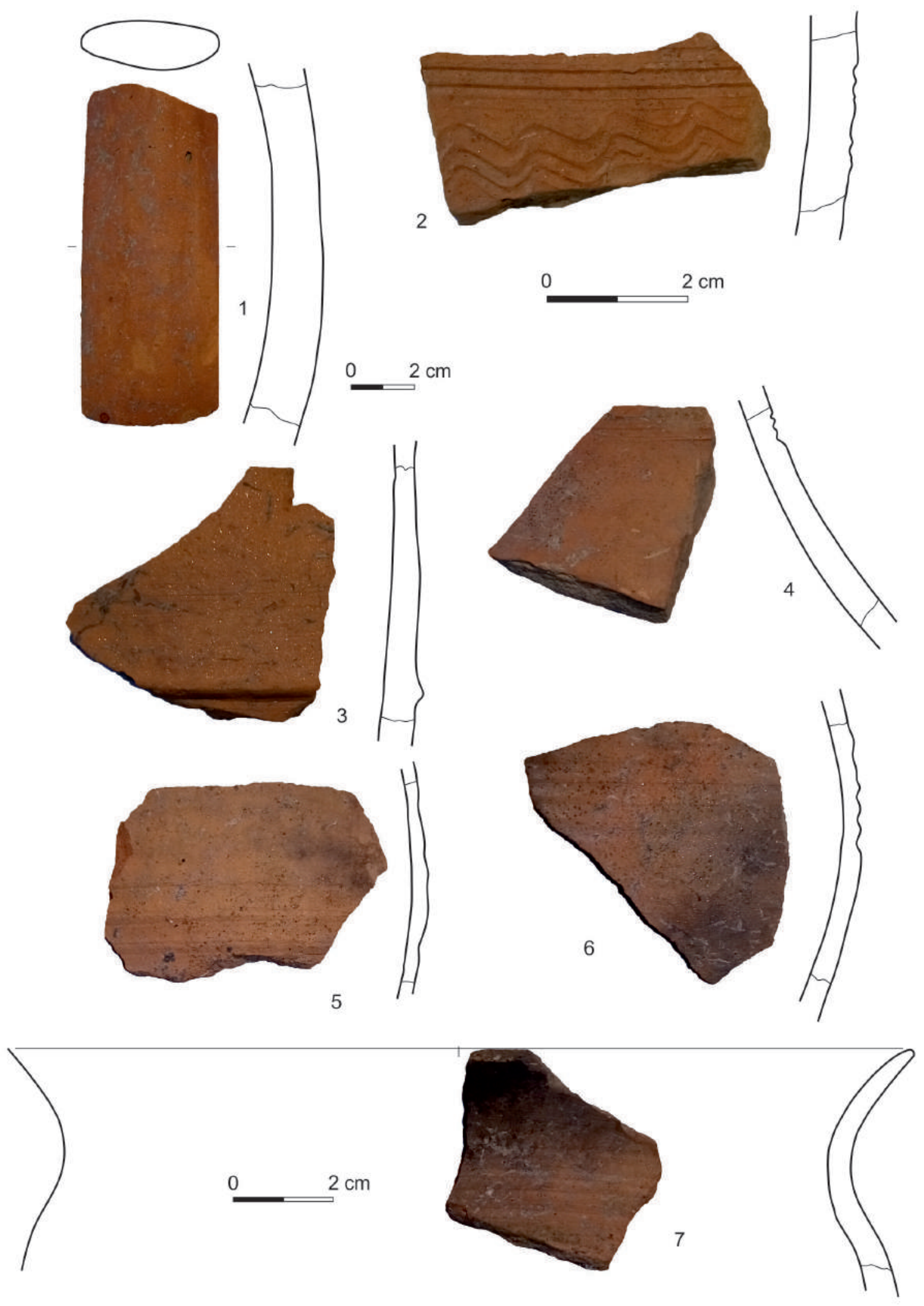

Fig. 22. Stațiunea de la Mirău. Cx3. Fragmente ceramice. 1-4. Pastă tip 1 (P1); 5-7. Pastă tip 2 (P2). 

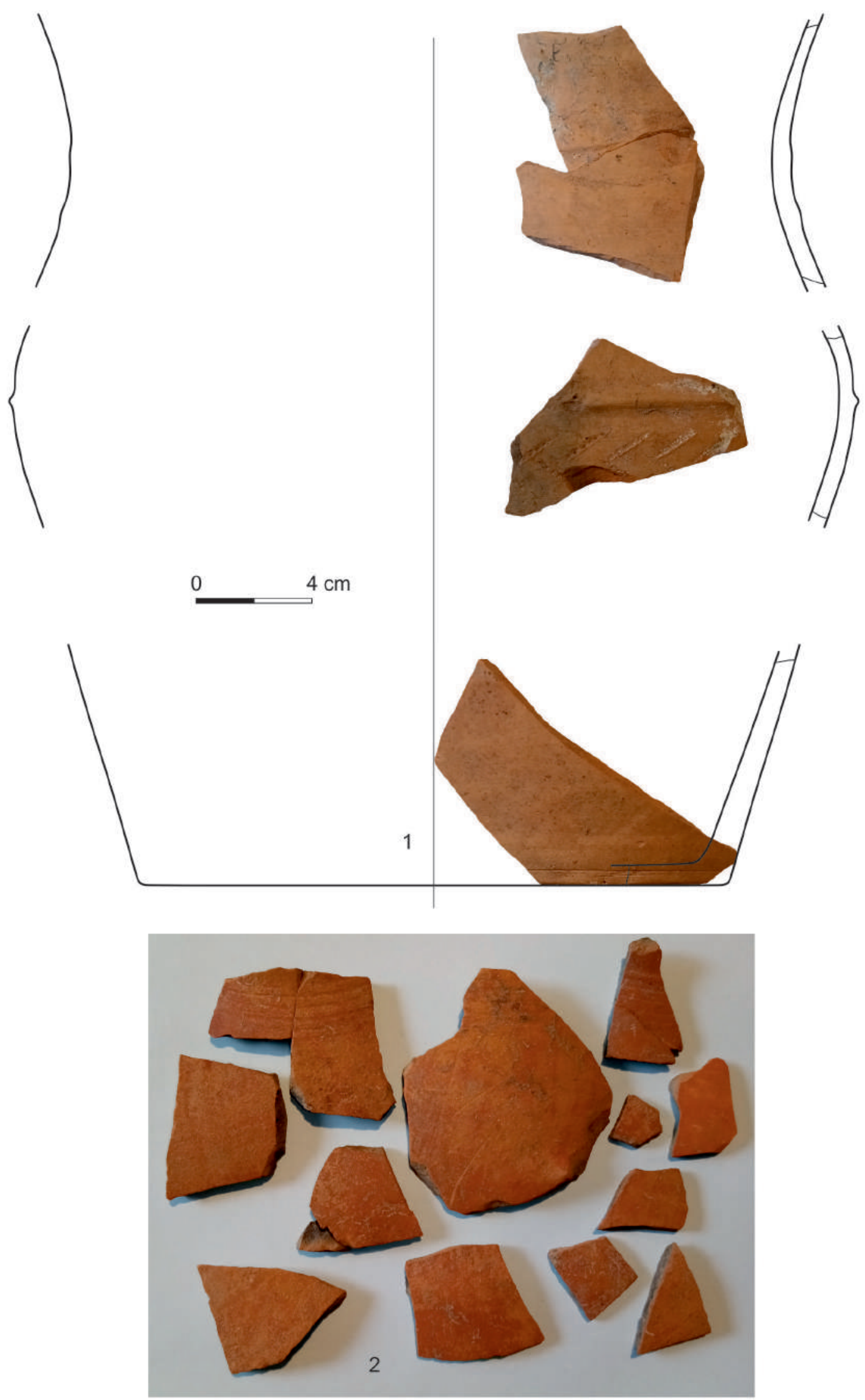

Fig. 23. Stațiunea de la Mirău. Ceramică. 1. Cx1 (primul moment de umplere), tipul de pastă 1 (P1), vas 8; 2. Cx1, US16, tipul de pastă 11 (P11). 

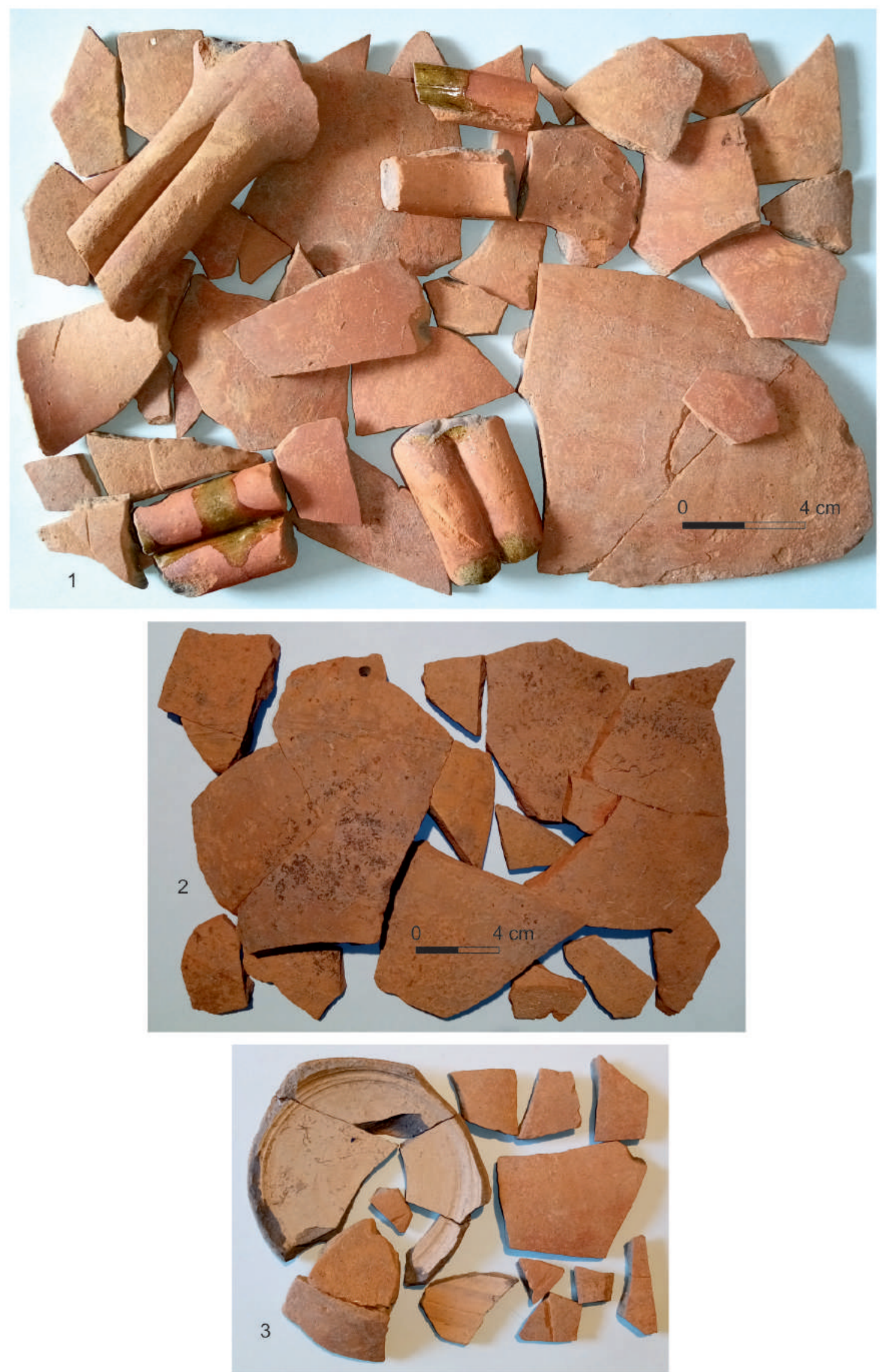

Fig. 24. Stațiunea de la Mirău. Ceramică. Cxl (primul moment de umplere), tipul de pastă 11 (P11). 1. Vas 1; 2. Vas 2; 3 . Vas 3. 

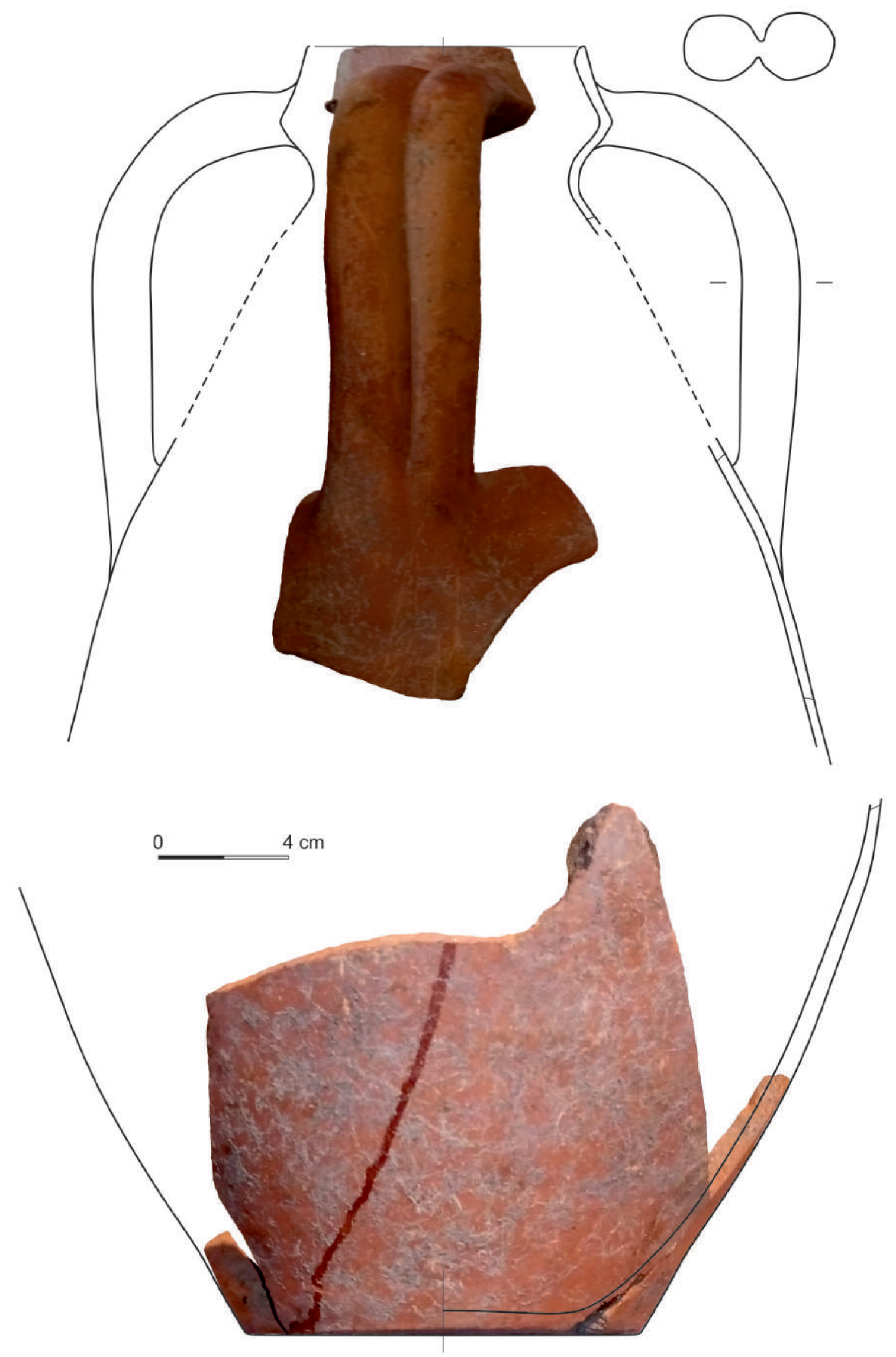

Fig. 25. Stațiunea de la Mirău. Ceramică. Cx1 (primul moment de umplere), tipul de pastă 11 (P11), Vas 1. 

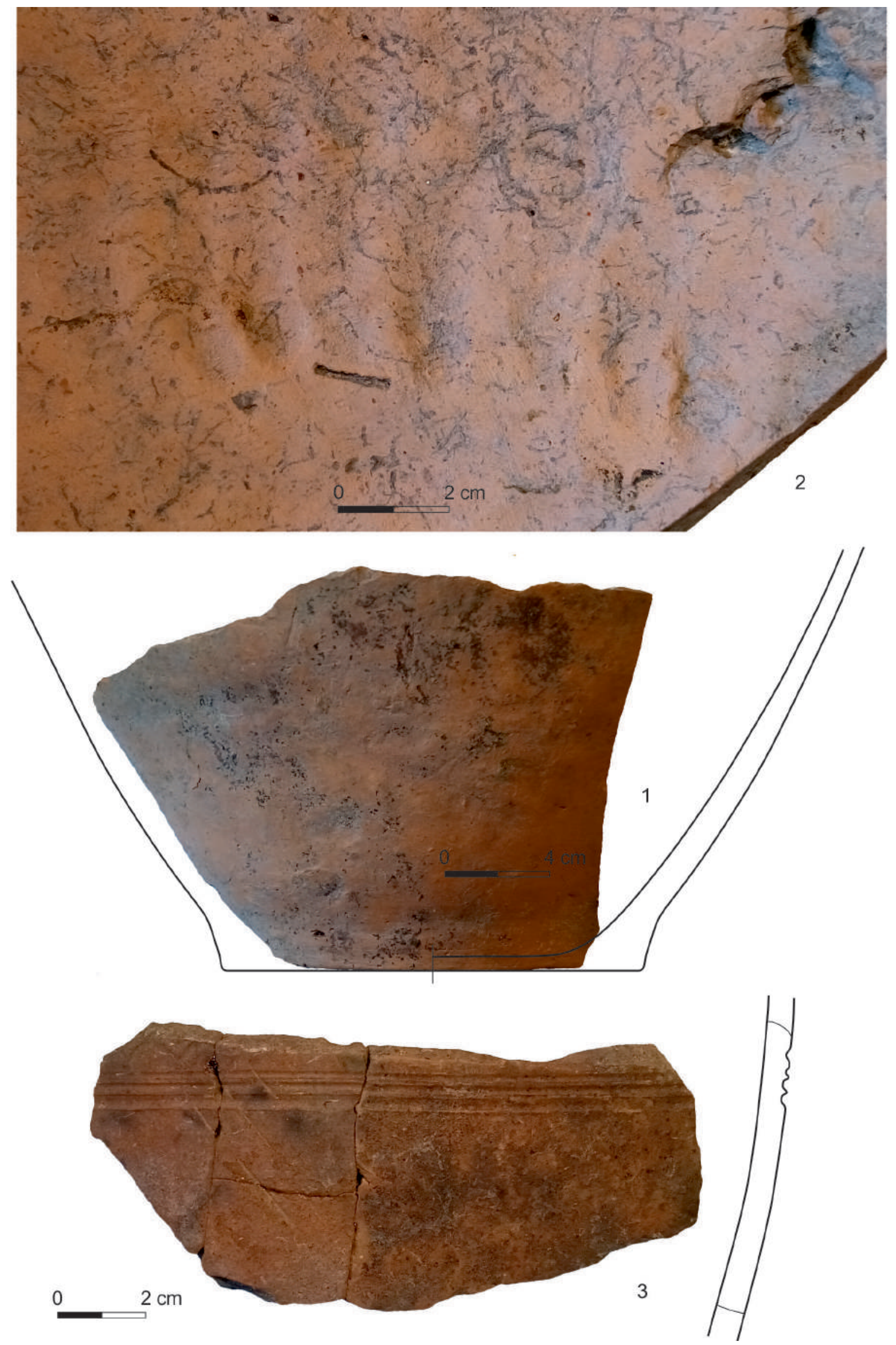

Fig. 26. Stațiunea de la Mirău. Ceramică. 1. Cx1 (primul moment de umplere), tipul de pastă 1 (P1), Vas 4 (2. detaliu interior); 3. Cx1 inf, tipul de pastă 11 (P11), Vas 6. 

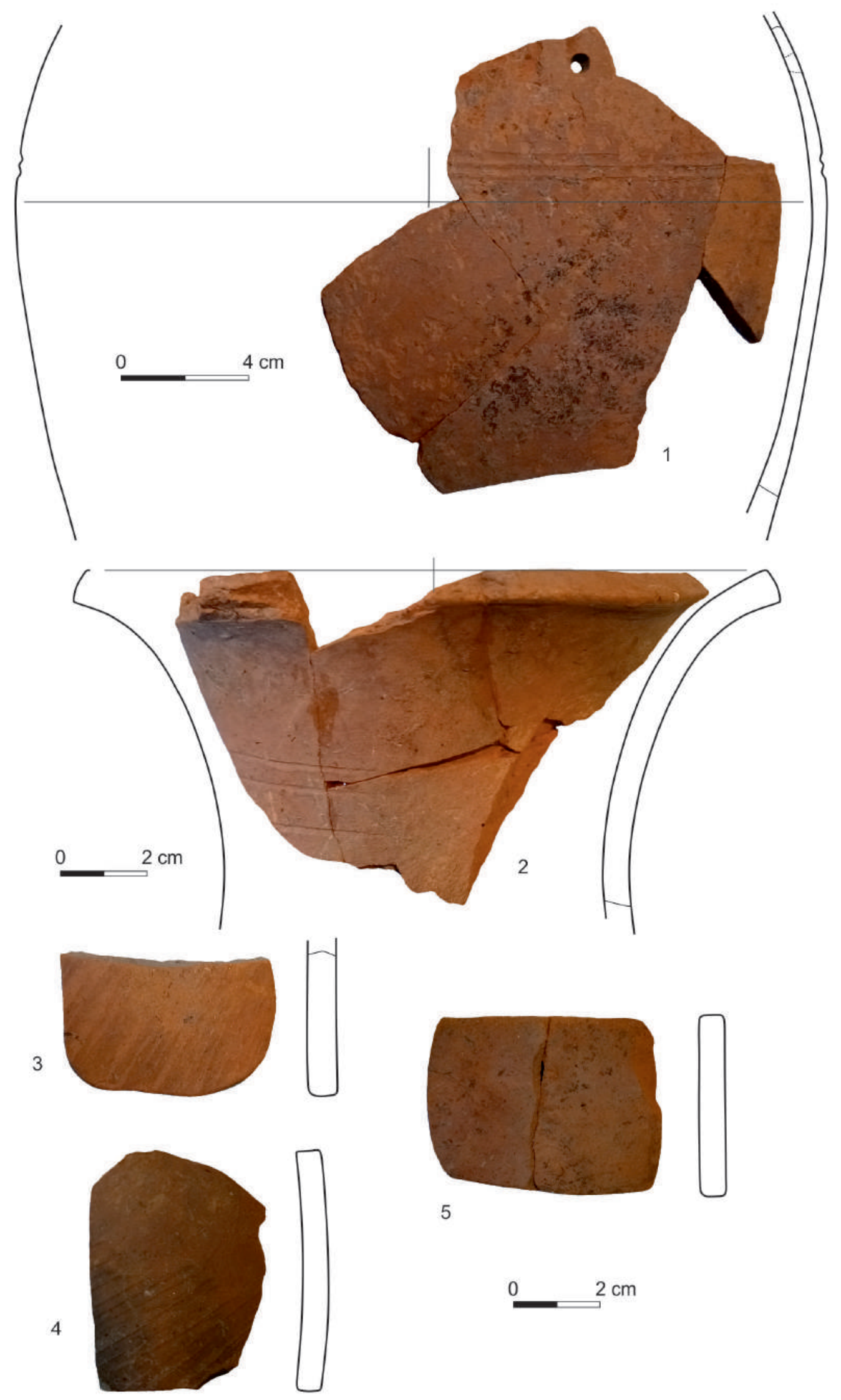

5

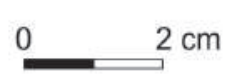

Fig. 27. Stațiunea de la Mirău. Ceramică Cx1 (primul moment de umplere), tipul de pastă 11 (P11). 1. Vas 2; 2. Vas 5; 3-5. Jetoane din fragmente ceramice. 

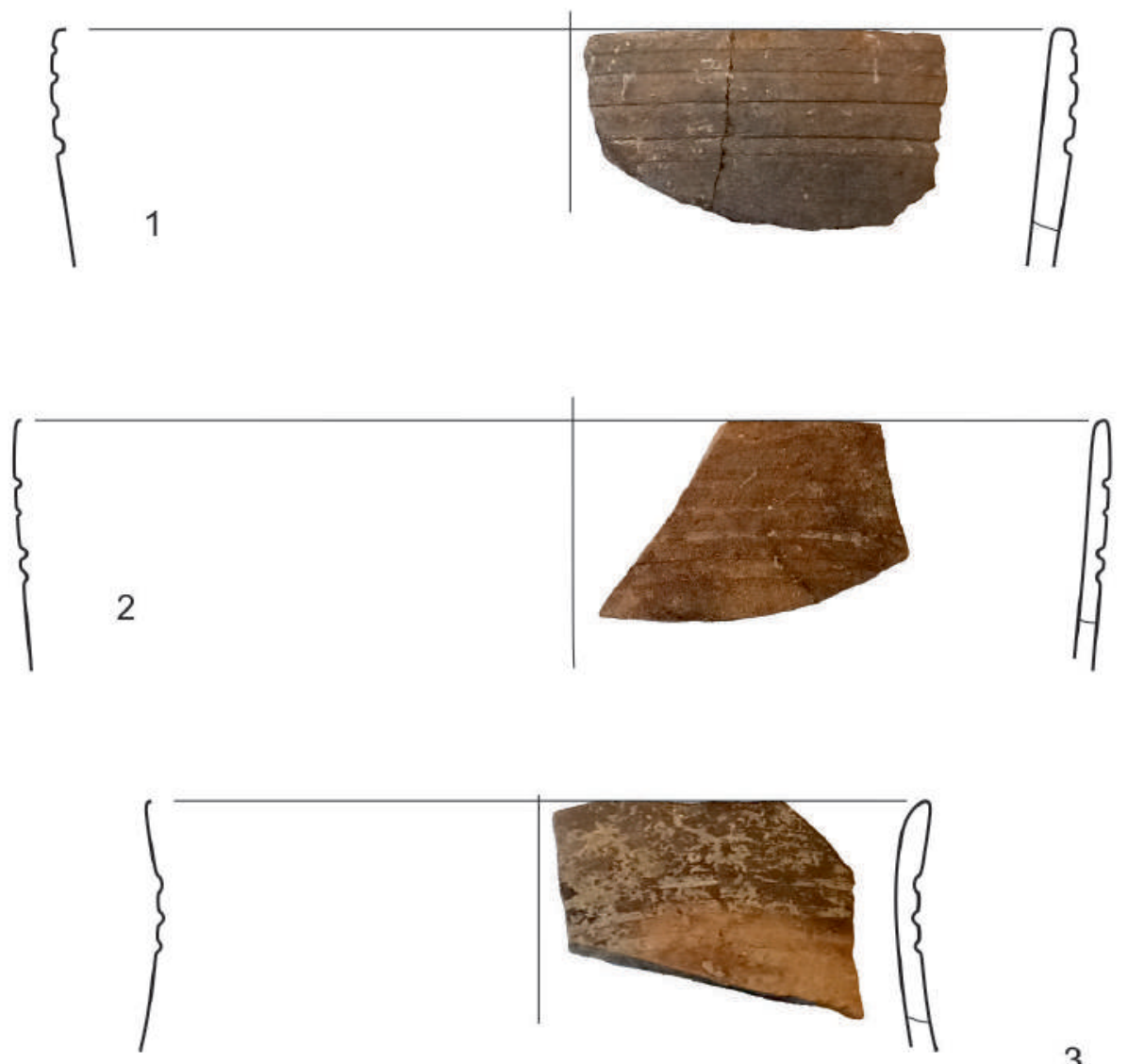

$\quad 2 \mathrm{~cm}$

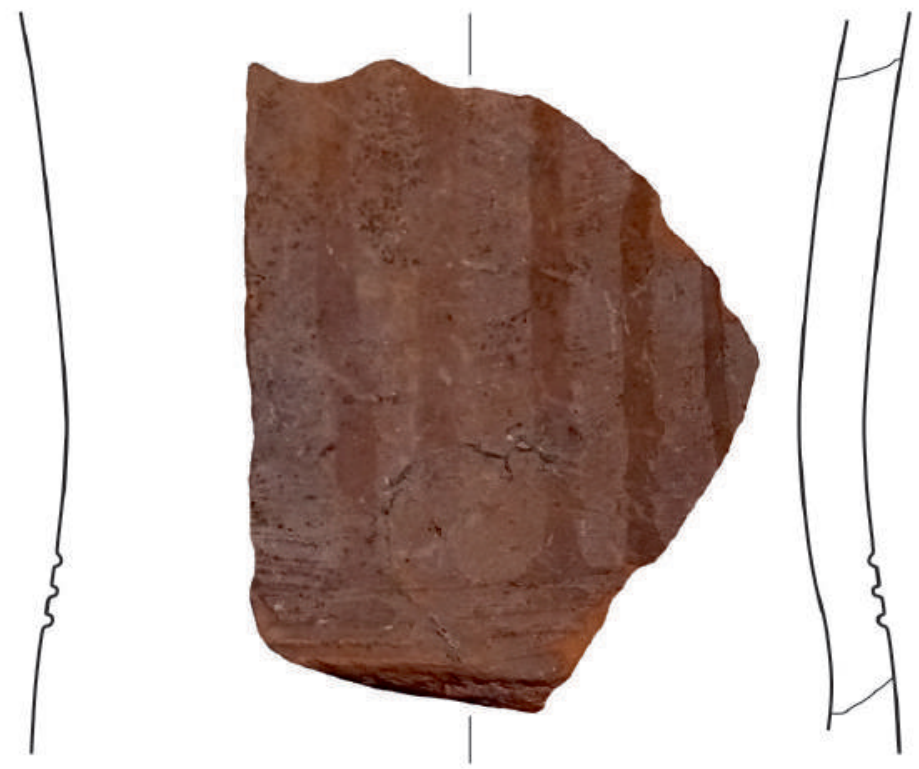

Fig. 26. Stațiunea de la Mirău. Ceramică. 1. Cx1 (primul moment de umplere), tipul de pastă 1 (P1), Vas 4 (2. detaliu interior); 3. Cx1 inf, tipul de pastă 11 (P11), Vas 6. 